
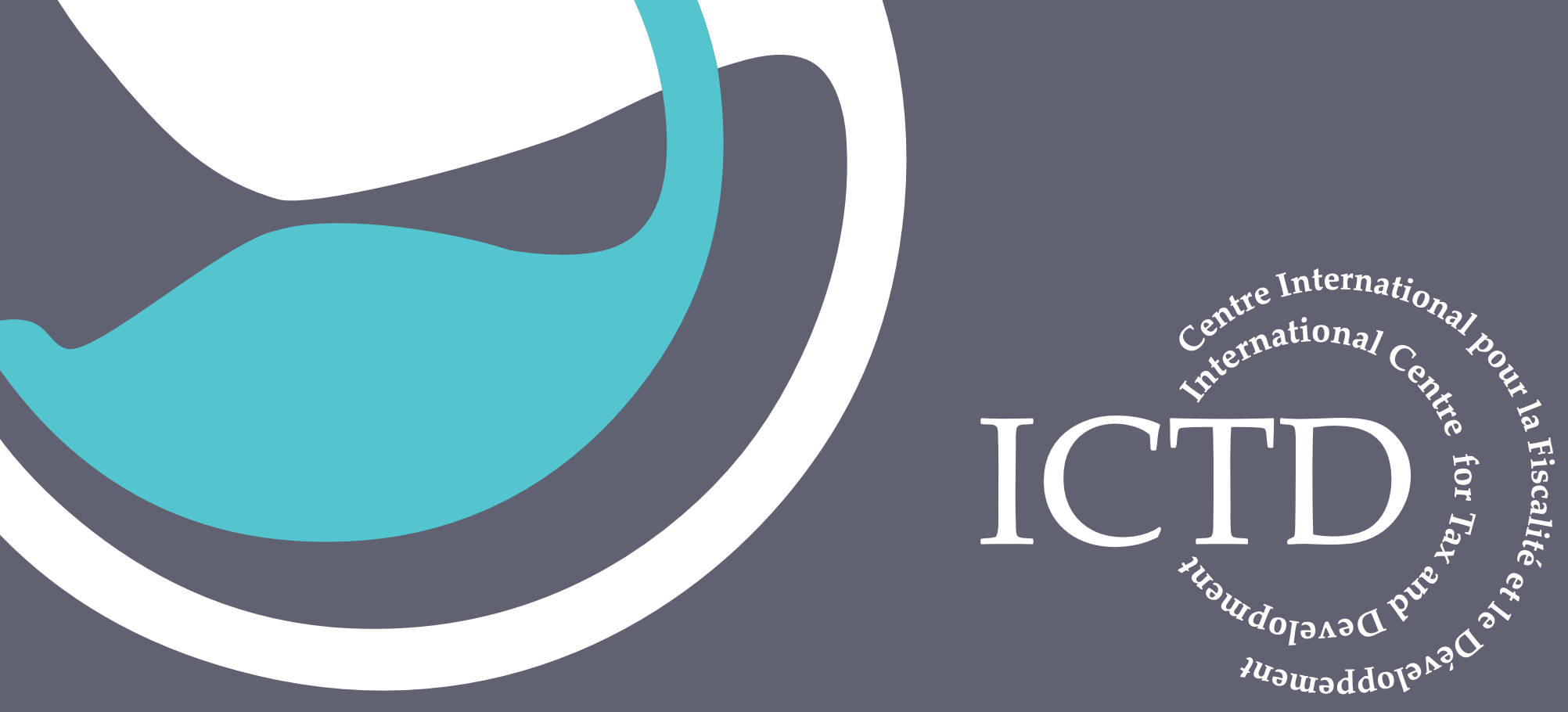

Working Paper 69

\title{
How Kenya has Implemented and Asdjusted to the Changes in International Transfer Pricing Regulations: 1920-2016
}

Attiya Waris

October 2017 
ICTD Working Paper 69

How Kenya has Implemented and Adjusted to the Changes in International Transfer Pricing Regulations: 1920-2016

Attiya Waris

October 2017 
How Kenya has Implemented and Adjusted to the Changes in International Transfer Pricing Regulations: 1920-2016 Attiya Waris

ICTD Working Paper 69

First published by the Institute of Development Studies in October 2017

(C) Institute of Development Studies 2017

ISBN: 978-1-78118-357-1

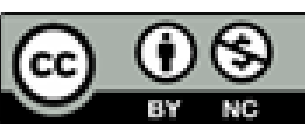

This is an Open Access paper distributed under the terms of the Creative Commons Attribution Non Commercial 4.0 International license, which permits downloading and sharing provided the original authors and source are credited - but the work is not used for commercial purposes. http://creativecommons.org/licenses/by-nc/4.0/legalcode

Available from:

The International Centre for Tax and Development at the Institute of Development Studies, Brighton BN1 9RE, UK Tel: +44 (0) 1273606261

Email: info@ictd.ac.uk

Web: www.ictd/en/publications

IDS is a charitable company limited by guarantee and registered in England

Charity Registration Number 306371

Charitable Company Number 877338 


\title{
How Kenya has Implemented and Adjusted to the Changes in International Transfer Pricing Regulations: 1920-2016
}

\author{
Attiya Waris
}

\section{Summary}

A large proportion of international trade in goods and services is conducted between what are known technically as related parties. In practice, most of this trade is between different companies forming part of the same transnational corporate grouping. This is typically highly integrated in economic and financial terms, while legally appearing as a set of separate companies incorporated in a wide range of countries.

For accounting, customs and general tax purposes, any two related companies engaging in cross-border transactions need to decide the price that they will set for the goods and services they exchange - ideally they will not make a profit off each other, as would be the case with unrelated companies. Inevitably, however, these are not market prices but administered prices. The process of setting these prices is known as transfer pricing (TP). In principle there is a standard mechanism, agreed internationally, to guide transfer pricing the arm's length principle. This means that cross-border transactions between related parties should be booked at the prices that would have applied had these been open competitive market transactions between unrelated parties (arm's length transactions). It can be extremely difficult - and sometimes impossible - for revenue authorities to apply the arm's length principle in daily operations.

This paper analyses Kenya's experience of trying to deal with transfer pricing, and looks at difficulties facing developing and middle-income countries in the application of transfer pricing rules. It discusses the course Kenya has taken in introducing TP laws, regulations, policies and administrative training in order to audit TP transactions effectively. Section 1 sets out the background to Kenya, its position in the African continent and globally, explaining why it has been selected as a case study. Section 2 sets out the historical experience of Kenya, both in developing its TP laws, regulations and procedures, as well as building capacity of its staff on issues of transfer pricing. Sections 3 and 4 reflect on the Kenyan position as set out in Section 2, and the appropriateness of some of the changes being proposed internationally by Actions 8-10 and 13 of the BEPS project of the G20/OECD. This paper attempts to unpack the issues surrounding TP in a developing country like Kenya, and to reflect on what is really needed in the BEPS process to make it usable in developing countries. The paper concludes by stating that the issues being raised in TP have been only partially resolved through improved capacity, regulations and policy. The OECD BEPS process does not seem to resolve problems faced by countries like Kenya, but instead foists a set of complex and unwieldy rules on Kenya and other developing and middle-income countries.

Keywords: transfer pricing; cross-border taxation; Kenya; Africa; tax avoidance; base erosion and profit shifting.

Attiya Waris is an advocate, arbitrator and senior lecturer at the Law School, University of Nairobi in Kenya, where she has been teaching for over twelve years. Attiya is author of several taxation articles and books, including Tax and Development: Solving Kenya's Fiscal Crisis through Human Rights (2013) and Transfer Pricing in Rwanda (2014). 


\section{Contents}

Summary 3

Acknowledgements $\quad 6$

$\begin{array}{ll}\text { Acronyms } & 6\end{array}$

$\begin{array}{ll}\text { Introduction } & 7\end{array}$

$1 \quad$ Taxing MNEs and transfer pricing in Kenya $\quad 8$

$2 \quad$ The development of transfer pricing laws in Kenya 14

2.1 From colonisation (1886) to independence (1964) 14

2.2 The post-independence period (1964 to 1998) 16

2.3 The Unilever case and its effect on TP law and practice (1998-2012) 17

2.4 The Karuturi case and current practice (2012-2016) 20

$3 \quad$ Current TP challenges and successes 23

3.1 Legislative framework 23

3.2 Capacity 24

3.3 The audit process 24

3.4 Governance 26

3.5 Technical obstacles 26

3.5.1 Comparables $\quad 26$

3.5.2 Choice of method 27

3.5.3 Access to information 28

3.6 Some success 29

$4 \quad$ Analysing BEPS solutions in the Kenyan context 30

4.1 The legal framework and its interpretation 31

4.2 Capacity 32

4.2.1 Revenue authority capacity 32

4.2.2 Tribunal and judiciary capacity 32

4.3 Governance 33

4.4 Technical obstacles within existing transfer pricing regulations 33

4.4.1 Comparables 33

4.4.2 Choice of TP method 34

4.4.3 Access to information 34

4.5 Unresolved technical obstacles within the BEPS regulations 36

$5 \quad$ Recommendations $\quad 37$

$\begin{array}{lll}6 & \text { Conclusion } & 37\end{array}$

$\begin{array}{ll}\text { Appendices } & 39\end{array}$

References $\quad 43$

Figures

Figure 1 Direct and portfolio investments - inward and outward investment (IDI derived data only) 9

Figure 2 Geographical coverage of the EAC-COMESA-SADC region 11

Figure 3 Tax collection 2005/6 to 2014/15 22 


\section{Acknowledgements}

Work on this paper was made possible by the Systems of Tax Evasion and Laundering (STEAL) project funded by the TaxCapDev programme under the Research Council of Norway (\#212210/H30), the REDE Project under the International Centre for Tax and Development and the Global Policy Centre, Institute of Austrian and International Tax, Business and Economics University of Vienna. It has also benefitted immensely from extensive reviews by Professor Sol Picciotto, to whom the author is most grateful.

\section{Acronyms}

$\begin{array}{ll}\text { APA } & \text { Advanced pricing agreement } \\ \text { ATAF } & \text { African Tax Administration Forum } \\ \text { AU } & \text { African Union } \\ \text { BEPS } & \text { Base erosion and profit shifting } \\ \text { BIT } & \text { Bilateral investment treaty } \\ \text { CbCR } & \text { Country-by-country reporting } \\ \text { CUP } & \text { Comparable uncontrolled price } \\ \text { DTA } & \text { Double taxation agreement } \\ \text { EAC } & \text { East African Community } \\ \text { EU } & \text { European Union } \\ \text { FDI } & \text { Foreign direct investment } \\ \text { GAAP } & \text { General anti-avoidance provision } \\ \text { IAS } & \text { International accounting standards } \\ \text { LTO } & \text { Large Taxpayers Office } \\ \text { KRA } & \text { Kenya Revenue Authority } \\ \text { MCAA } & \text { Multilateral Competent Authority Agreement } \\ \text { MCMAATM } & \text { Multilateral Convention on Mutual Administrative Assistance in Tax Matters } \\ \text { MNE } & \text { Multinational enterprise } \\ \text { OECD } & \text { Organisation for Economic Co-operation and Development } \\ \text { TIEA } & \text { Tax information exchange agreement } \\ \text { TP } & \text { Transfer pricing } \\ \text { UNECA } & \text { United Nations Economic Commission of Africa } \\ \text { VAT } & \text { Value added tax }\end{array}$




\section{Introduction}

While moving towards a simpler, more equitable, transparent and broad-based tax system has been a concern of developing countries for decades, even the most basic understanding of a tax system can be overwhelming. Data shows that half of sub-Saharan African countries still mobilise less than 15 per cent of their GDP in tax revenue, below the minimum level of 20 per cent considered by the UN as necessary to achieve the Millennium Development Goals by 2015 (Waris and Kohonen 2011). Unlike developed countries, some of the poorest countries rely very heavily on corporate tax revenue from multinational enterprises (MNEs). It is therefore critical that developing countries are able to tax the full profits that are realised in their jurisdictions, and to reduce opportunities for MNEs to artificially separate the allocation of their taxable profits from the jurisdictions in which those profits arise.

Transfer pricing (TP) refers to the pricing of intra-group, cross-border transactions between related parties. It is vulnerable to manipulation, including the deliberate misuse or misapplication of transfer pricing rules. ${ }^{1}$ However, in many ways the most important and difficult issue is how to determine appropriate criteria for allocating the profits earned by an MNE between its various constituent parts. From an economic or business perspective MNEs operate as integrated firms, but from a legal perspective they often consist of hundreds of separately incorporated companies formed in various countries. In the calculation of corporate tax, a company's revenue is based on its sales, which are assumed to be set at the current market price. Legally allowable expenditure is deducted to calculate taxable profit. However, this assumption does not hold when sales are to related companies that are part of the same corporate group. This also applies to other transactions between related parties, such as interest on loans, fees for services, or royalties for intellectual property rights. Since these additional payments are usually deductible before calculation of tax, they reduce taxable profits.

International tax rules have, from their beginning, given powers to revenue authorities to adjust the accounts of associated enterprises within a multinational corporate group.

However, these rules have been ambivalent (Picciotto 2017a). While powers to adjust are granted in cases where related parties are not independent of one another, the principle to be applied is that their income should reflect what it would have been if they were independent. The application and enforcement of this rule has come under increasing global scrutiny and criticism as being unenforceable, and unfavourable for developing countries. As a result, the G20/OECD have been working on reforming the rules under the base erosion and profit shifting (BEPS) project. It is intended that BEPS Actions 8-10 will introduce considerable changes to the OECD Transfer Pricing Guidelines, and Action 13 introduces new standard templates for transfer pricing documentation and country-by-country reporting (OECD 2010, 2015a, 2015b).

In Africa, awareness of the issues surrounding transfer pricing is varied. Although this issue has a long history, it is only relatively recently that revenue authorities have begun to apply it in a systematic way. In the past, revenue collectors have rarely audited, investigated and successfully collected taxes by the application of transfer pricing rules. In 2015 the African Union (AU) and United Nations Economic Commission of Africa (UNECA) listed only three African countries - Kenya, South Africa and Uganda - as having separate transfer pricing units within their revenue collection agencies (AU/UNECA 2015). However, by early 2016 the Natural Resource Governance Institute added Tanzania, Nigeria, Senegal, Tunisia and Angola, and stated that Guinea and Sierra Leone are in the process of setting them up

Transfer mispricing expresses itself in six ways: (i) intentional falsification of information; (ii) non-declaration of financial assets; (iii) trade mispricing; (iv) accounting fraud; (v) bribing tax officials; and (vi) abuse of tax incentives by falsely claiming eligibility. 
(Readhead 2016: 19). As a result currently there are only eight TP units, with an additional two being set up, out of the fifty-four African countries. While initial concerns about the difficulty in enforcing TP rules were partially resolved by building capacity and training TP staff within a TP unit in revenue agencies, the development of these units now allows reflection on the effectiveness of a trained TP Unit. A second and more important concern should also be addressed: whether the TP rules themselves are suitable or appropriate in a developing country context. This paper tests their suitability for Kenya, which has been actively building its TP capacity and revising its laws, regulation and policies in order to effectively audit transactions on the basis of the OECD TP rules.

Section 1 sets out the background to Kenya, its position in the African continent and globally, explaining why it has been selected as a case study. Section 2 sets out the historical experience of Kenya, both in developing its TP laws, regulations and procedures, as well as building capacity of its staff on issues of transfer pricing. Sections 3 and 4 reflect on the Kenyan position as set out in Section 2, and the appropriateness of some of the changes being proposed internationally by Actions 8-10 and 13 of the BEPS project of the G20/OECD. This paper attempts to unpack the issues surrounding TP in a developing country like Kenya, and to reflect on what is really needed in the BEPS process to make it usable in developing countries. Sections 5 and 6 give recommendations and conclusions.

\section{Taxing MNEs and transfer pricing in Kenya}

Kenya is probably one of the most interesting countries in the developing world and in Africa to study for both international tax purposes and transfer pricing. There are several reasons.

First, Kenya has an active international trade and investment network with many countries. The investment network is illustrated graphically in Figure 1, which shows inflows and outflows of foreign direct investment (FDI) and portfolio investment based on IMF data as at 2012. The main countries from which these investments flow are: the UK, Mauritius, the Netherlands, Luxembourg, France, South Africa, United States, Switzerland, Germany, Turkey, Italy, India, Denmark, Republic of Korea, Brazil, Norway and Russia. 


\section{Figure 1 Direct and portfolio investments - inward and outward investment (IDI derived data only) ${ }^{2}$}

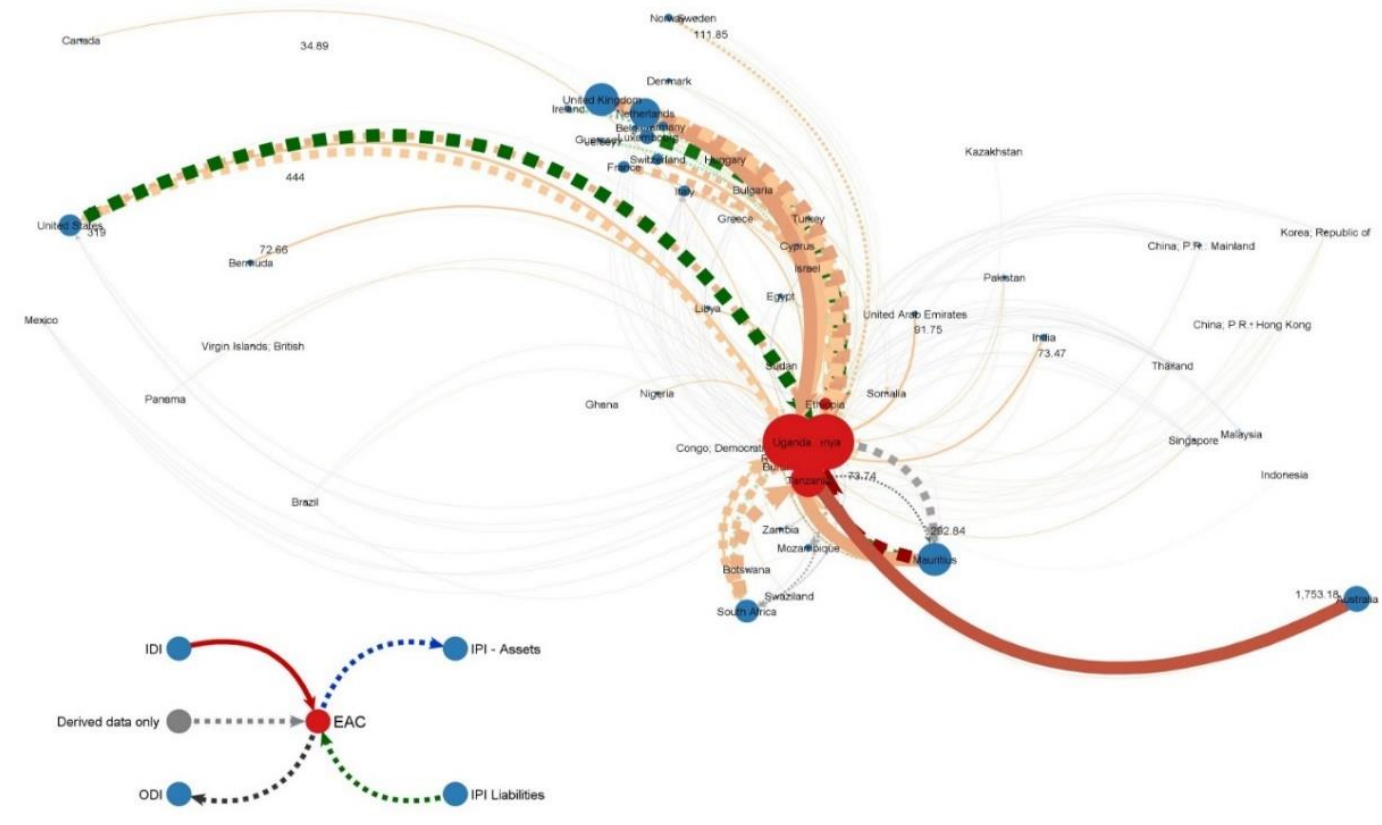

Source: STEAL (Douglas 2015)

Kenya also has ten active double taxation agreements (DTAs), as shown in Table 1. Not all Kenya's DTAs are with the major investing partners: there is no DTA with the Netherlands, Luxembourg, United States, Switzerland, Republic of Korea, Brazil or Russia. There also seems to be no correlation with Kenya's main trading partners, which include Saudi Arabia, Japan, United States, Pakistan and Egypt (KNBS 2014). ${ }^{4}$ Many African countries have either no DTAs or only one DTA, usually with its former colonising state. Few have more than ten. The major exceptions are Mauritius, which has forty-three DTAs, with others under negotiation, and South Africa, which has over eighty.

Table 1 Kenya's international tax treaties

\begin{tabular}{|l|l|l|l|l|}
\hline \multirow{2}{*}{ Year } & \multirow{2}{*}{ Country } & \multicolumn{2}{|l|}{ Status } & Comments \\
\cline { 3 - 5 } & & $\begin{array}{l}\text { Date of } \\
\text { signature }\end{array}$ & $\begin{array}{l}\text { Ratification } \\
\text { Legal notice no. }\end{array}$ & DTA in force \\
\hline 1970 & Zambia & 27.8 .1968 & $10 / 1970^{*}$ & DTA in force \\
\hline 1973 & Norway & 13.12 .1972 & $6 / 1973^{\star}$ & DTA in force \\
\hline & Denmark & 13.12 .1972 & $5 / 1973^{*}$ & DTA in force \\
\hline & Sweden & 28.6 .1973 & $14 / 1973^{\star}$ & DTA in force \\
\hline 1977 & UK & 31.7 .1973 & $253 / 1977^{*}$ & DTA in force \\
\hline 1980 & Germany & 17.5 .1977 & $20 / 1980^{*}$ & DTA in force \\
\hline 1987 & Canada & 27.4 .1983 & $111 / 1987$ &
\end{tabular}

Inward direct investments derived means this data does not actually exist but are economic estimates.

See note 1 .

Kenya's other trading partners include Uganda, Tanzania, Rwanda, Burundi, Egypt, South Africa, European Union (EU), United Kingdom, Saudi Arabia, United Arab Emirates, United States of America, Japan, Pakistan and India. 


\begin{tabular}{|c|c|c|c|c|}
\hline 1989 & India & 12.4.1985 & $61 / 1989$ & DTA in force \\
\hline 2009 & France & & $140 / 2009$ & DTA in force \\
\hline 2016 & Italy & 3.3 .2016 & & DTA in force \\
\hline \multirow[t]{22}{*}{2016} & South Africa & 26.11 .2010 & $141 / 2014$ & DTA in force \\
\hline & EAC & & $142 / 2014$ & $\begin{array}{l}\text { DTA signed, not in force } \\
\text { (signed: Kenya and Rwanda) }\end{array}$ \\
\hline & Iran & & Legal Notice No. 60/2014 & $\begin{array}{l}\text { DTA signed, not in force } \\
\text { (awaiting ratification in Iran) }\end{array}$ \\
\hline & Kuwait & & Legal Notice No. 149/2014 & DTA signed, not in force \\
\hline & Mauritius & & Legal Notice No. 59/2014 & DTA signed, not in force \\
\hline & Seychelles & & Legal Notice No. 9/2015 & DTA signed, not in force \\
\hline & Thailand & & & DTA under negotiation \\
\hline & Ethiopia & & & DTA under negotiation \\
\hline & Turkey & & & DTA under negotiation \\
\hline & Qatar & & & DTA in discussion \\
\hline & Nigeria & & & DTA in discussion \\
\hline & Finland & & & DTA in discussion \\
\hline & Russia & & & DTA in discussion \\
\hline & UAE & & & DTA in discussion \\
\hline & Isle of Man & & & TIEA signed but not ratified \\
\hline & Bermuda & & & TIEA signed but not ratified \\
\hline & Liechtenstein & & & TIEA signed but not ratified \\
\hline & $\begin{array}{l}\text { Cayman } \\
\text { Island }\end{array}$ & & & TIEA signed but not ratified \\
\hline & Malta & & & TIEA signed but not ratified \\
\hline & Jersey & & & TIEA signed but not ratified \\
\hline & Monaco & & & TIEA signed but not ratified \\
\hline & Guernsey & & & TIEA signed but not ratified \\
\hline
\end{tabular}

Key: DTA = double tax agreement;

TIEA = tax information exchange agreement

* $=$ DTA existed before independence and was renegotiated after independence Source: KRA (2016); Chege (2013); Tax Wise Consulting (2016)

Kenya also has bilateral investment treaties (BITs) in force with France, Germany, Netherlands, Switzerland and the UK, and BITs signed but not in force with Burundi, China, Finland, Iran, Kuwait, Libya, Mauritius, Slovakia and Turkey. These treaties, while not tax treaties, include non-discrimination and fair treatment obligations that can affect a wide range of domestic regulatory powers, including tax (Picciotto 2016). Negotiation of these treaties is the responsibility of the Ministry of Finance, while a prior discussion takes place in the Task Force on Double Taxation and Investment Agreements. The Task Force is chaired by the Ministry of Finance, and includes members of the policy unit of the Kenya Revenue Authority (KRA). It is unclear how much weight is given to tax revenue considerations in the negotiations. 
Second, Kenya forms part of the East African Community (EAC), and borders several landlocked countries. ${ }^{5}$ It is one of the few relatively peaceful countries in the region, but has several conflict-prone neighbours. ${ }^{6}$ Therefore it is important regionally as a source of goods and services for the regional economy. The signing of the EAC-COMESA-SADC Tripartite Agreement in June 2015 has increased the market access of businesses based in Kenya from 40 million Kenyans and 140 million East Africans, to 600 million people, as shown in Figure 2 and Table 2 below (EAC 2016).

Figure 2 Geographical coverage of the EAC-COMESA-SADC region

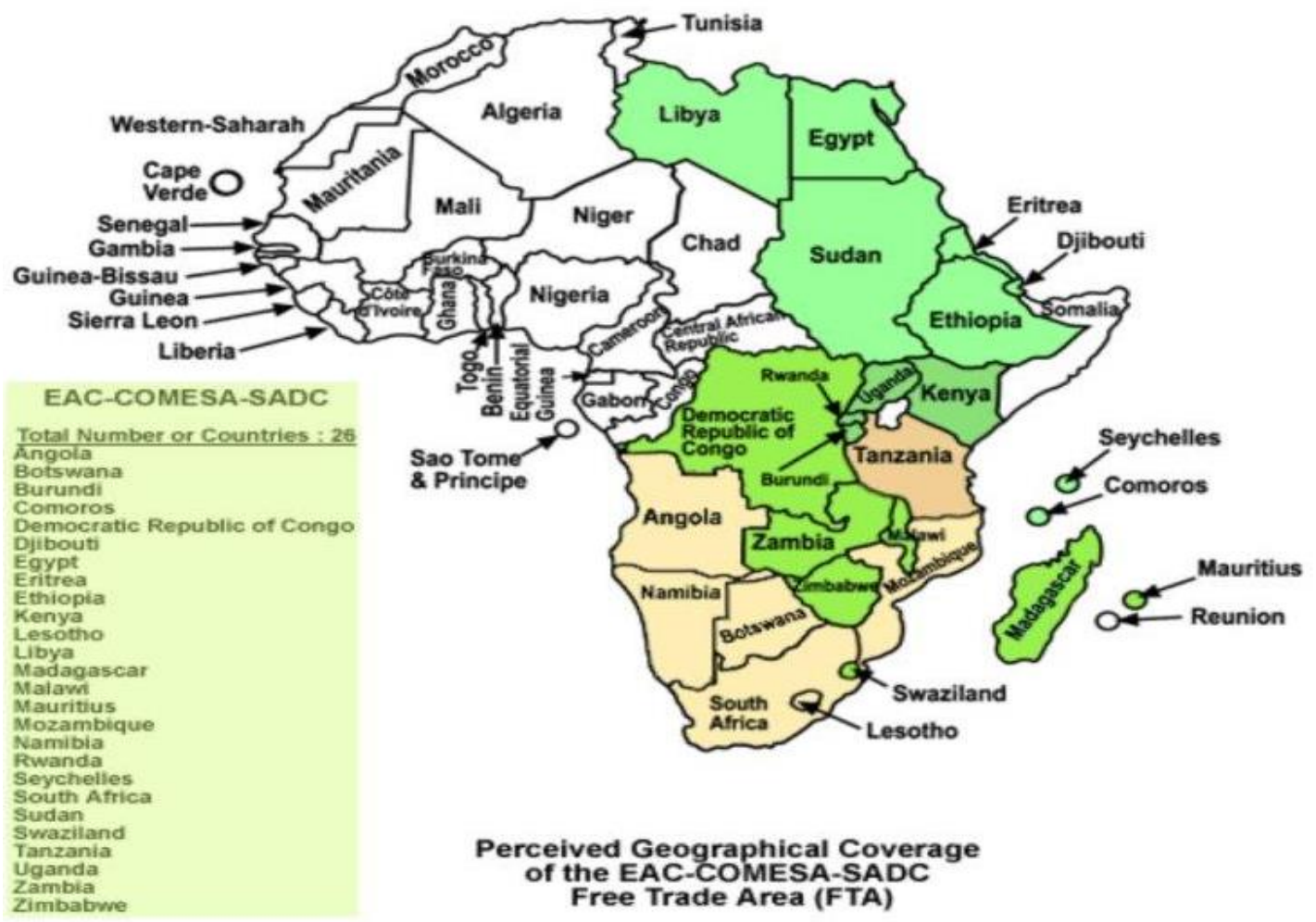

Source: EAC 2016

Uganda and South Sudan, whose neighbours include Rwanda and Burundi. South Sudan, Somalia and nearby Burundi. 
Table 2 Population and GDP of the SADC-EAC-COMESA region

\begin{tabular}{|c|c|c|c|c|c|}
\hline Country & GDP, US\$' m & Population, '000 & $\begin{array}{c}\text { GDP per capita, } \\
\text { US\$ }\end{array}$ & $\begin{array}{c}\text { GDP per } \\
\text { capita/day, } \\
\text { US } \$\end{array}$ & $\begin{array}{c}\text { GDP } \\
\text { Country } \\
\text { Share, \% }\end{array}$ \\
\hline South Africa & 254,992 & 47,391 & $5,380.60$ & 14.74 & 40.84002 \\
\hline Angola & 44,033 & 16,391 & $2,686.41$ & 7.36 & 7.052411 \\
\hline Libya & 50,320 & 5,965 & $8,435.88$ & 23.11 & 8.05935 \\
\hline Ethiopia & 13,315 & 72,712 & 183.12 & 0.50 & 2.132556 \\
\hline Tanzania & 12,784 & 39,477 & 323.83 & 0.89 & 2.04751 \\
\hline Zambia & 10,907 & 11,862 & 919.49 & 2.52 & 1.746886 \\
\hline Botswana & 10,328 & 1,758 & $5,874.86$ & 16.10 & 1.654153 \\
\hline Uganda & 9,322 & 29,874 & 312.04 & 0.85 & 1.49303 \\
\hline Namibia & 6,372 & 2,051 & $3,106.78$ & 8.51 & 1.020552 \\
\hline Madagascar & 5,499 & 19,087 & 288.10 & 0.79 & 0.880731 \\
\hline Zimbabwe & 5,010 & 13,086 & 382.85 & 1.05 & 0.802411 \\
\hline Swaziland & 2,648 & 1,126 & $2,351.69$ & 6.44 & 0.424109 \\
\hline Rwanda & 2,494 & 9,244 & 269.80 & 0.74 & 0.399444 \\
\hline Malawi & 2,232 & 13,163 & 169.57 & 0.46 & 0.357481 \\
\hline Lesotho & 1,476 & 1,789 & 825.04 & 2.26 & 0.236399 \\
\hline Eritrea & 1,085 & 4,538 & 239.09 & 0.66 & 0.173776 \\
\hline Burundi & 807 & 7,833 & 103.03 & 0.28 & 0.129251 \\
\hline Djibouti & 757 & 806 & 939.21 & 2.57 & 0.121243 \\
\hline Seychelles & 750 & 86 & $8,720.93$ & 23.89 & 0.120121 \\
\hline Comoros & 403 & 614 & 656.35 & 1.80 & 0.064545 \\
\hline
\end{tabular}

Source: World Bank 2006

Third, Kenya was among the first countries in Africa to try to strengthen its enforcement of international taxation, including transfer pricing rules. Even before the creation of the Kenya Revenue Authority in 1995, the revenue office under the Ministry of Finance and Treasury was divided into four departments called districts. District 4 focused on corporate income tax, and included a special unit focusing on MNEs. ${ }^{7}$ Work of this special unit resulted in the audit of Netherlands-owned Unilever, and subsequent litigation in the High Court of Kenya (Unilever v The Commissioner General, KRA 2005). Since 2011 the KRA has been involved in litigation with the Indian-owned flower exporter Karuturi, which as at January 2017 was still unresolved (Karuturi Limited v Commissioner of Domestic Taxes, undecided). These are the only TP cases to have reached the courts in Eastern and Central Africa, and are discussed in more detail in Section 2. Despite efforts to monitor and prevent transfer mispricing, it remains unclear whether they have resulted in a significant and consistent increase in government revenue. The data on income tax revenue from corporations between 2005 and 2014 set out in Table 3 and Figure 3 below shows increased collections. However, the reasons for this growth remain unclear, and will be discussed in more detail in Section 2.4. 
Table 3 Corporate tax revenue 2005-2014

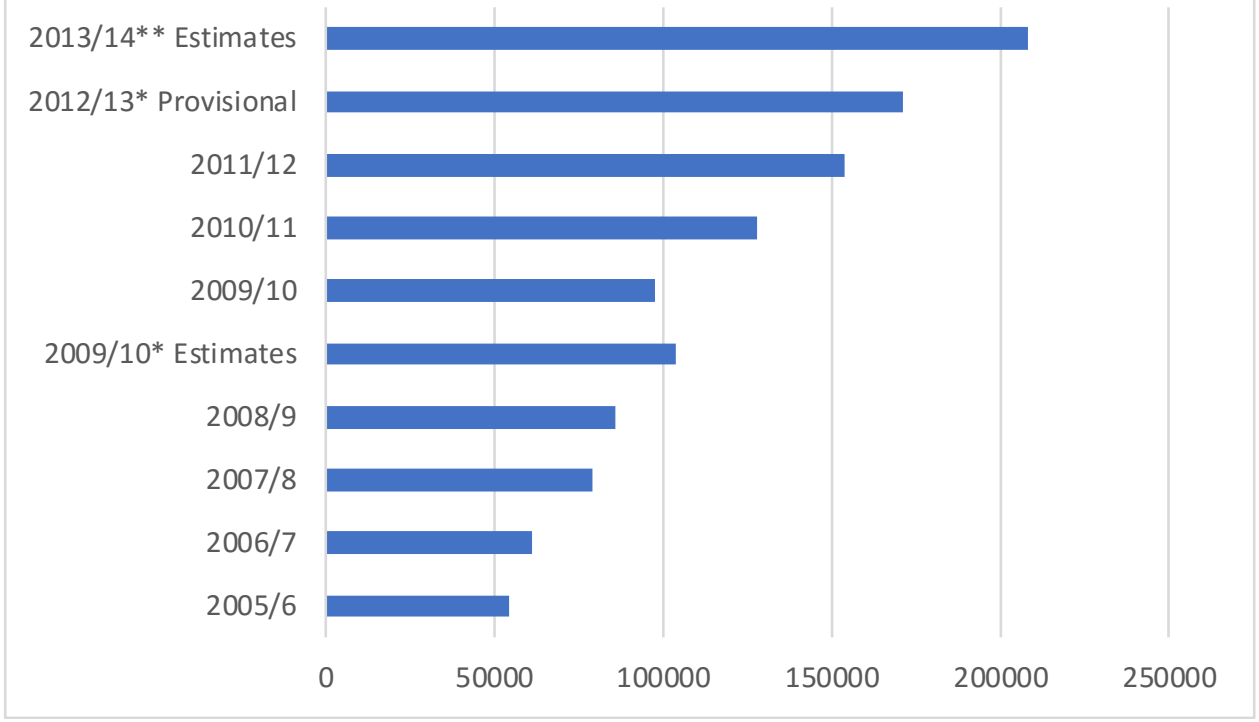

Source: derived from KRA (2016); Prichard et al. (2014)

Fourth, Kenya is a developing country that achieved middle-income country status in 2015. This was done through re-analysis of data and rebasing of its economy, which resulted in increasing nominal gross domestic product by 25 per cent to $\$ 55$ billion (World Bank 2016). A reflection on Kenya's challenges over the past eighteen years may provide options for both developing and developed countries to consider as they decide how to approach crossborder issues, including international tax and transfer pricing. Kenya has the largest economy in East Africa, ninth in Africa, and the fourth largest in sub-Saharan Africa, after Nigeria, South Africa and Angola. Kenya was listed as the second most preferred destination for MNEs in Africa by the Frontier Strategy Group, coming after Nigeria (Gachiri 2014), and fifth by Mail and Guardian Africa (M \& G Africa 2015).

Fifth, Kenya is in an unusual position as an African country that not only hosts foreign multinationals and often their regional hubs (Kelley 2011), ${ }^{9}$ but also has its own large homegrown multinationals, as set out in Table 4.

Table 4 Large MNEs with headquarters in Kenya

\begin{tabular}{|l|l|l|l|l|l|}
\hline & MNE & $\begin{array}{l}\text { Countries } \\
\text { of } \\
\text { presence }\end{array}$ & Sector & $\begin{array}{l}\text { Turnover } \\
(2011)(\text { US } \$)\end{array}$ & $\begin{array}{l}\text { Companies above/below } \\
€ 750,000 \text { million annual } \\
\text { turnover }\end{array}$ \\
\hline 1. & Kenol/Kobil & $\begin{array}{l}\text { Kenya, } \\
\text { Uganda }\end{array}$ & Petroleum & $1,221,130$ & Above \\
\hline 2. & Safaricom & & Telecom & $1,379,876$ & Above \\
\hline 3. & Kenya Airways & & Transport & $1,030,321$ & Above \\
\hline 4. & Kenya Power & & Telecom & 878,002 & Above \\
\hline 5. & Total Kenya & & Petroleum & 772,342 & Above \\
\hline 6. & $\begin{array}{l}\text { East African } \\
\text { Breweries } \\
\text { (Group) }\end{array}$ & $\begin{array}{l}\text { Kenya, } \\
\text { Uganda }\end{array}$ & Commodity & 455,5844 & Below \\
\hline
\end{tabular}

Data on income tax from corporations in Kenya includes tax on income, profits and capital gains.

These include Google, Visa, MasterCard, KFC, Pepsi, Travelport and Dow Chemicals, which have chosen Nairobi for either their regional or African headquarters. 


\begin{tabular}{|c|c|c|c|c|c|}
\hline 7. & $\begin{array}{l}\text { East African } \\
\text { Breweries } \\
\text { (Kenya) }\end{array}$ & & Commodity & 414,780 & Below \\
\hline 8. & $\begin{array}{l}\text { Bamburi } \\
\text { Cement }\end{array}$ & & Construction & 336,900 & Below \\
\hline 9. & Nakumatt & $\begin{array}{l}\text { Rwanda, } \\
\text { Uganda, } \\
\text { Tanzania }\end{array}$ & $\begin{array}{l}\text { Commodity } \\
\text { (retail) }\end{array}$ & 334,358 & Below \\
\hline
\end{tabular}

Source: extracted from IGD \& DGDA (2011)

Other African countries with MNEs having an annual turnover higher than $€ 750$ million include Nigeria, South Africa, Morocco, Egypt, Libya and Mauritius (IGD and DGDA 2011). This makes Kenya one of the select African and developing countries that will not only be a receiver of information, but also a provider or sharer of information under new BEPS regulations on country-by-country reporting (discussed in more detail in Section 4). Kenya's MNEs operate predominantly within East Africa, and the KRA will have to share data with other East African countries, including Uganda, Tanzania, Rwanda, South Sudan and Somalia.

Finally, in several articles and reports being produced on international tax law, Kenya is often cited as an African developing country that has been successfully using the OECD transfer pricing regulations to increase revenue collection since 2010. Corrick claims that OECD training helped the KRA to increase its revenue collection through transfer pricing audits from US\$52 to US\$107 million in 2014 (Corrick 2016: 196).

The following sections look at some key questions. What are the Kenyan transfer pricing laws, and how have they developed (Section 2)? Do current OECD transfer pricing rules, which are similar to the Kenyan rules, allow states to share revenue appropriately (Section 3)? Under existing international rules, what steps does a country like Kenya, and its revenue authority, need to take in order to effectively collect taxes (Section 4)?

\section{The development of transfer pricing laws in Kenya}

While some African countries have no laws in their income tax legislation dealing with issues of TP, Kenya is one of the few that has provisions covering issues of cross-border tax dating back to the colonial era. This section will set out and analyse Kenya's attempts to tax crossborder transactions from before independence up to 2016.

\subsection{From colonisation (1886) to independence (1964)}

The British Colonial Office tried to implement income tax in its Kenya colony in 1920. This was met with stiff opposition, with the result that the 1920 Income Tax Ordinance was amended in 1922 to state that not only would no income tax be levied, but anything already collected would be refunded (British Colonial Office 1922a). It was replaced as a revenue source by import duties on foodstuffs, particularly wheat, sugar and tea (Swainson 1980: 25).

In this period the British Inter-departmental Committee on Income Tax had prepared a Colonial Model Income Tax Ordinance for colonies not possessing 'responsible government' (British Colonial Office 1922b). The Committee dealt with the taxation of profits from crossborder business in its report to the Colonial Office, and recommended application of the approach adopted in the UK. The UK position was that where a non-resident carried on 
business through an agent resident in the colony, tax should apply on profits gained by trading in the Colony but not from trade with the Colony (British Colonial Office 1922b: 42). It cited the report of the Royal Commission on Income Taxation (1919-20), which concluded that no reasonably short definition could be made of this distinction. As regards determination of the level of profit, it recommended against adoption of the rule that had been introduced in Trinidad, which provided that where the level of profit could not be easily ascertained, a presumption should be applied that it should be 10 per cent of the selling price. It preferred instead the UK approach of 'leaving the taxing authority, in any case where the actual profits which the non-resident derives from his trade within the country cannot be ascertained, to fix such a fair and reasonable percentage as the facts of the particular case may justify' (British Colonial Office 1922b: 39). The model law put forward a TP provision that stated in article 27(2):

Where a non-resident person, not being a British subject, or a firm or company whose principal place of business is situated in His Majesty's Dominions or in territory under His Majesty's protection, or a branch thereof, carries on business with a resident person, and it appears to the Commissioner that owing to the close connection between the resident person and the non-resident person and to the substantial control exercised by the non-resident person over the resident person, the course of business between those persons can be so arranged and is so arranged, that the business done by the resident person in pursuance of his connection with the nonresident person produces to the resident person either no profits or less than the ordinary profits which might be expected to arise from that business, the non-resident person shall be assessable and chargeable to tax in the name of the resident person as if the resident person were an agent of the non-resident person.

This is very similar to Section 31(3) of the 1915 Finance Act of the UK, and even today similar forms of this provision are found in former British colonies, such as Jamaica.

Income tax was finally introduced in the Kenya colony in 1933, with a change of both the governorship of the colony and a power shift away from the Kenyan Legislative Council and towards the Colonial Office in the UK (Dilley 1966). In 1937 an income tax law finally passed the Kenyan Legislative Council (Income Tax Ordinance 1937). The Ordinance included an identical TP provision at article 27(2) to the one set out in the 1922 model ordinance cited above.

The 1922 Ordinance also included a general anti-avoidance provision (GAAP) - Section 22b - which stated: 'where the assessing officer is of the opinion that any transaction which reduces or would reduce the amount of tax payable by any person is artificial or fictitious or that any disposition is in fact not given effect to, he may disregard any such transaction or disposition and the person concerned would be assessable accordingly'.

This GAAP is believed to have originated from the English Excess Profit Duty legislation of 1915, which mentioned fictitious or artificial transactions. The Kenya Income Tax Ordinance was revised in 1940, but maintained a similar GAAP provision as section 23 (Kenya Colony 1940a; Kenya Colony 1940b). There is no reported case law within this period, and the provision remained untested.

In 1952 the three ordinances governing income tax (Kenya Colony 1940a; Kenya Colony 1940b; Kenya Colony 1941) were combined into the East African Income Tax (Management) Act 1952. In addition to including the already-mentioned TP and GAAP provisions, section 16(2)(j) set out thin capitalisation rules, disallowing deduction of interest for companies other than banks if loans exceeded three times the equity of the company, where it is in the control of a non-resident person, alone or together with four or fewer other persons. 
The TP provision in the East Africa Tax Management Act 1952 at section 4 provided:

\begin{abstract}
Where an enterprise of one of the territories participates directly or indirectly in the management, control or capital of an enterprise of the other territory, or the same person participate directly or indirectly in the management, control or capital of an enterprise of one of the territories and the enterprise of the other territory, and in either case, conditions are either made or imposed between the two enterprises, in their commercial or financial relations, which differ from those of which would be made between independent enterprises, any profit which would but for those conditions have accrued to one of the enterprises but by reason of those conditions have not so accrued may be included in the profits of that enterprise and taxed accordingly.
\end{abstract}

This text essentially reproduces article 9 of the model tax treaties, but differs significantly from the TP provision introduced in the UK the previous year (Finance Act 1951, s.37). However, there does not appear to be any published instance of the application of this provision, and no reported transfer pricing cases before independence, although the Act of 1952 remained in place until independence in 1964 and included sections 4 (which replaced section 27(2) - the TP provision set out earlier) and section 22 (the GAAP). As a result, at independence there was a TP provision, a GAAP and a thin capitalisation rule.

\title{
2.2 The post-independence period (1964 to 1998)
}

As part of the transition to independence all existing legislation remained in place, as well as any UK international agreements that had been extended to Kenya. In addition, the three East African states (Kenya, Tanganyika/Tanzania and Uganda) continued to be part of the East African Community (EAC), and the East African Tax Management Act remained in force until 1970 when the EAC was dissolved. Kenya renegotiated the existing six DTAs (set out in Table 1 above) that were negotiated before independence, although no changes were made to the text of the treaties. Upon the dissolution of the EAC in 1970, Kenya re-enacted the 1940 Kenya Income Tax Ordinance as the Income Tax Act of 1970, maintaining most of the same provisions but without reference to the Crown. As a result, section 23 of the Kenya Income Tax Act remained in force as the GAAP. The transfer pricing provision was similarly adopted by using the 1940 version of section 27(2) set out above, but re-numbered as Section 18(3). The TP provision in section 18(3) states that:

(3) Where a non-resident person carries on business with a related resident person and the course of that business is so arranged that it produces to the resident person either no profits or less than the ordinary profits which might be expected to accrue from that business if there had been no such relationship, then the gains or profits of that resident person shall be deemed to be the amount that might have been expected to accrue if the course of that business had been conducted by independent persons dealing at arm's length.

This provision is similar to one found in many Commonwealth countries, including Jamaica and the Solomon Islands. It is clearly aimed at an arrangement between a resident and nonresident person that results in little or no profit, which today is commonly referred to as base erosion and profit shifting. However, the true intent and spirit of the legislation is not clear whether to ensure a balance in the attribution of profits, or to act as an anti-avoidance rule.

There was neither case law nor legislative reform regarding the enforcement of cross-border tax issues after independence up to 1998. The elaboration of procedures by issuance of additional regulations was left as a power of the minister of finance under section 18, but was never acted upon. The Revenue Office, then still under the Ministry of Finance, undertook a Tax Modernisation Programme in 1986, and in 1995 the KRA was established as a semi- 
autonomous corporate entity (Moyi and Ronge 2006). This led to the setting up of a separate unit for the audit of MNEs under the corporate income tax department. The Taxpayers' Office was divided into four districts. District 4 dealt only with corporate income tax, and housed a special unit that focused solely on MNEs.

\subsection{The Unilever case and its effect on TP law and practice (1998-2012)}

By 1998 , there were only six DTAs in force in Kenya. ${ }^{10}$ The only relevant legal provision on international tax and transfer pricing at the time were sections 16, 18 and 23 of the Income Tax Act, cited above, with no regulations for its procedural application. Between independence and 2000, the Institute of Certified Accountants of Kenya developed the Kenyan Accounting Standards as guidelines for accounting of cross-border transactions. However, these were being replaced on a piecemeal basis by the International Accounting Standards (IAS) by the late 1990s. Kenya had been applying the IAS since 2000, and as a result the TP regulations (Appendix C) were tied in with IAS no 24 (IASB 2012). ${ }^{11}$ The objective of this Standard is to ensure that the financial statements of an entity contain the information necessary to demonstrate that the financial position as the result of the exercise has not been affected by the existence of related parties and of transactions conducted with them (IASB 2012; Income Tax Act 2012).

The TP provision in section 18(3) remained untested until a routine audit in 1998 by the special unit focusing on MNEs. A member of the special unit who had been allocated to audit Unilever noticed a discrepancy in the prices of goods manufactured by Unilever (Kenya), but sold in Uganda by Unilever (Uganda). Unilever (Kenya) was manufacturing washing powder and toothpaste and transferring them to Unilever (Uganda) for sale in Uganda under a contract of 1995. Unilever (Kenya) also manufactured and sold such products to customers in Kenya, and to other unrelated customers in the export market. The audit found that Unilever (Kenya) charged lower prices to Unilever (Uganda) than those charged both to customers in Kenya and to unrelated parties in the export market both in Uganda and elsewhere (Unilever v The Commissioner General, KRA 2005: 2).

Applying the principle of comparability, the price charged to a related party should be benchmarked with the price charged to third parties, taking into account the circumstances of the case. The KRA proposed an adjustment of profits based on local comparables, after adjusting for transport costs. In effect this applied the Comparable Uncontrolled Price (CUP) method outlined in the 1995 OECD Transfer Pricing Guidelines. However, the KRA did not refer explicitly to the CUP. Unilever claimed that they approached the comparability issue using the OECD Transfer Pricing Guidelines, since section 18(3) was insufficiently specific. Unilever argued that the CUP was unsuitable, since the sales to unrelated parties referred to by the KRA were not actually comparable. It cited several reasons, including the different mix of products involved, as well as the costs of marketing in Kenya (Unilever v The Commissioner General, KRA 2005:6). Instead of using the CUP, Unilever (Kenya) had therefore used the cost plus method, as accepted in the OECD Transfer Pricing Guidelines.

The KRA set up a transfer pricing unit in 2000 , after the Commissioner General of taxation directed his staff to provide additional audit support for the Unilever case. ${ }^{12}$ This was the only case that the TP unit was examining at that point in time, and five members of staff were

10 Zambia, Norway, Denmark, Sweden, UK and Germany; these did not include the Netherlands (headquarters of Unilever), or Uganda.

11 This standard applies to: (a) identification of relationships and transactions between related parties; (b) identifying outstanding balances between an entity and its related parties; (c) identification of circumstances that requires disclosure about (a) and (b) above, and (d) the determination to disclose information on these headings. It requires disclosure of related party transactions and outstanding balances with them in the separate financial statements of a dominant participant in a joint venture or an investor, prepared in accordance with IAS 27 Consolidated and Separate Financial Statements.

$12 \quad$ Interview 2. 
allocated to the case. ${ }^{13}$ KRA proceeded to conduct an in-depth audit followed by protracted negotiations, but failed to come to an agreed outcome with Unilever. This led to an appeal to the Local Committee which the KRA won, and, finally, an appeal to the High Court of Kenya by Unilever. In arguing the application of section 18(3), the KRA stated that Unilever (Kenya) was simply giving a discount to their related company in Uganda, and the Local Committee upheld this argument. However, the Local Committee did not give reasons for their decision, and as result the High Court decided to reconsider the entire case.

In 2004 the High Court decided in favour of Unilever, based on two main limbs. First, that there were no regulations under section 18(3), and as a result the OECD Transfer Pricing Guidelines would be applied; second, that the section was itself unclear, placing burden of proof on the Commissioner General and not the taxpayer.

On the first limb, the KRA argued that the OECD Transfer Pricing Guidelines did not apply, since they were not referred to anywhere in Kenyan law, and, in any case, had no more than advisory status. This was rejected in a remarkable decision by Justice Visram, who opined: "We live in what is now referred to as a "global village". We cannot overlook or side line what has come out of the wisdom of taxpayers or tax collectors in other countries. And, especially because of the absence of any such guidelines in Kenya, we must look elsewhere' (Unilever v The Commissioner General; KRA 2005:13).

The decision rested on the view that the burden was on the KRA to justify the adjustment it had made. Although the KRA could do this in principle by referring to the CUP, which was the method preferred by the OECD Transfer Pricing Guidelines, it failed to rebut the data provided by Unilever regarding lack of comparable data. This can be attributed to lack of experience at the time of applying these rules of both the KRA audit staff and the Local Committee, and it could be argued both the lawyer litigating the case and the High Court judge who heard the case. Since Kenya is not a member of the OECD, this decision in effect bound Kenya to the recommendations of an organisation it was not part of, and to the Transfer Pricing Guidelines it was not involved in formulating and had never assented to. There was also no mention of the UN Guidelines as an alternative for the judge to consider.

The transfer pricing unit that had been set up during the case was disbanded after the judge's decision, as the view at the KRA was that it was too difficult to collect any revenue through transfer pricing. Since staff were working on - and rewarded according to achievement of - tax collection targets, the problems with transfer pricing meant that KRA staff were unwilling to be located in the transfer pricing unit. Pending cases were settled or dropped. In Sara Lee Household \& Body Care Limited $v$ KRA, an appeal pending in the High Court, where it was evident that the appellant would rely heavily on the Unilever decision, the Commissioner and the appellant negotiated an out-of-court settlement. Other cases were dropped without recovery of any taxes (Chege 2013).

Two legal changes took place, almost as though the KRA wanted to start again with a clean slate. First, section 18 was amended in line with the judge's decision, and second the Commissioner General issued regulations under section 18(3). Following the ruling in 2005, Kenya issued the Income Tax (Transfer Pricing Rules) 2006 to guide the application of Section 18(3) of the Income Tax Act. It is unclear who drafted these regulations or whether there was any external advice involved in the drafting, but they essentially followed the OECD Transfer Pricing Guidelines. Rule 4 specifies that 'The taxpayer may choose a method to employ in determining the arm's length price from among the methods set out in rule 7', while rule 7 states: 
'7. Methods.

The methods referred to in rule 4 are the following-

(a) the comparable uncontrolled price (CUP) method, in which the transfer price in a controlled transaction is compared with the prices in an uncontrolled transaction and accurate adjustments made to eliminate material price differences;

(b) the resale price method, in which the transfer price of the produce is compared with the resale price at which the product is sold to an independent enterprise;

Provided that in the application of this method the resale price shall be reduced by the resale price margin (the profit margin indicated by the reseller);

(c) the cost plus method, in which costs are assessed using the costs incurred by the supplier of a product in a controlled transaction, with a mark-up added to make an appropriate profit in light of the functions performed, and the assets used and risks assumed by the supplier;

(d) the profit split method, in which the profits earned in very closely interrelated controlled transactions are split among the related enterprises depending on the functions performed by each enterprise in relation to the transaction, and compared with a profit split among independent enterprises in a joint venture;

(e) the transactional net margin method, in which the net profit margin attained by a multinational enterprise in a controlled transaction is compared to the net profit margin that would have been earned in comparable transactions by an independent enterprise; and

(f) such other method as may be prescribed by the Commissioner from time to time, where in his opinion and in view of the nature of the transactions, the arm's length price cannot be determined using any of the methods contained in these guidelines'.

The rules also gave the Commissioner General the power to require taxpayers to supply documentation justifying the choice of transfer pricing methods, including information about 'the global organisation structure of the enterprise'.

The second limb identified by the judge was the ambiguity in section 18(3). In 2010 Section 18(3) of the Income Tax Act was amended, by deleting 'so arranged' and substituting 'such' (Income Tax Act 2010: section 24).

The new version of section 18(3) now reads

(3) Where a non-resident person carries on business with a related resident person and the course of that business is such [italics added] that it produces to the resident person either no profits or less than the ordinary profits which might be expected to accrue from that business if there had been no such relationship, then the gains or profits of that resident person shall be deemed to be the amount that might have been expected to accrue if the course of that business had been conducted by independent persons dealing at arm's length.

This change was because the phrase 'so arranged', according to J. Visram in the Unilever case, suggested the presence of intention or a premeditated act which the Commissioner has to prove to sustain an assessment. The amendment aimed to lower the standard of proof required if the Commissioner is to make a transfer pricing adjustment. Under the revised provision, the Commissioner is only required to demonstrate that as a result of the commercial arrangement the transaction gave rise to less than normal tax, lowering the level of the burden of proof for the KRA. A further change expanded the definition of related party as applied to individuals to include relation by blood (consanguinity) and other close relationships (affinity) by amending section 18(6) (c). This recognised that much business in Kenya is carried out by individuals and families, rather than companies. 
At the regional level, the African Revenue Authority Commissioner Generals, of which Kenya was a founding member, created the African Tax Administration Forum (ATAF) in 2008. Its mandate included issues of cross-border taxation (ATAF 2016). Global concern, highlighted by organisations such as the Tax Justice Network, resulted in the beginning of a process of review of international taxation rules in 2009. ${ }^{14}$ The OECD set up the Tax and Development Task Force in 2009, and one of the most immediate results was agreement at the OECD that revenue authorities in developing countries were desperately in need of capacity building in issues of transfer pricing. Kenya was one of the first beneficiaries of this decision, in light of the Unilever case and its efforts to apply transfer pricing rules. ${ }^{15}$ The OECD also set up the Global Forum in 2011.

As part of the capacity-building programme, in 2011 the KRA created two teams of five people, both under a supervisor, to begin to audit MNEs. In the same year KRA purchased access to the Amadeus system, which gave some data on comparables, and audits began to take a different shape. In 2012 an amendment of rule 8 of the Transfer Pricing Rules 2006 empowered the Commissioner to issue guidelines specifying conditions and procedures for the application of the methods set out in rule 7. This was a response to the problems encountered in administration of arm's length principle. The Commissioner General could now issue guidelines and revise them whenever necessary. To enable the KRA to easily identify taxpayers with related party transactions, the taxpayer's annual income tax return was redesigned to facilitate disclosure of details of related party transactions. The related party information that is required to be disclosed under the 2012 regulations includes: loans advanced or received, sales and/or purchases, payment or receipt for services, intellectual property, head office expenses and payment towards cost contribution arrangements. These changes were made effective from 2012 using the Integrated Tax Management System (now iTax). Taxpayers engaged in related party transactions are identified, and the accounting ratios that show where a company is making more or less profit than its industry-specific counterparts are computed. This identifies taxpayers with transactions that are prima facie deemed non-compliant with the arm's length principle. The selected taxpayers are then subjected to further screening and, if found wanting, are subjected to a transfer pricing tax audit. It was in this period that the audit of Karuturi began. This is discussed in detail in the next section, which also highlights the current position of the KRA TP unit.

\subsection{The Karuturi case and current practice (2012-2016)}

The KRA TP team began auditing related party transactions under the revised regulations between 2010 and 2012. An audit of Sher Karuturi, an Indian-owned agricultural company with operations in the United Arab Emirates, revealed transfer mispricing. Available information is mainly from press releases, since the case remains unresolved. This is discussed here as it has been the main controversy in this period.

On 4 April 2013 Sher Karuturi (an Indian MNE) filed a notice of appeal against the decision of the Tax Tribunal for taxes due. The process of audit and negotiation had been ongoing for several years. According to the Indian Credit Rating Research Agency in an October 2012 analysis commissioned by Karuturi, as well as Karuturi's 2012 annual report, Karuturi registered a tax dispute with the KRA over transfer pricing involving KSh975 million (US\$10.7 million/€8 million). This was almost 1 per cent of Kenya's total tax collection in 2012. Since then newspaper reports suggest that the case went back into negotiation without any actual presentation of the facts in court, and the last report was that Karuturi had negotiated the

\footnotetext{
14 Interview 4. This interviewee credited civil society organisations especially for the debates surrounding country-bycountry reporting $(\mathrm{CbCR})$, pointed out that these rules were already being applied in the mining and telecom sectors, and that MNEs must get used to being more transparent. 
figure down to US\$40,000. Karuturi (Kenya) has been under intense criticism since 2013, and is now in receivership.

In making the TP assessment of Karuturi it seems that the KRA applied the comparable uncontrolled price (CUP) method. Under CUP, the transaction between related parties is compared to a transaction of the same goods in the same market under similar conditions between unrelated parties. The Karuturi case involved the export of roses to overseas markets through Flower Express, a related party situated in Dubai. Flower Express would buy all flowers produced by Karuturi on 'free-on-board Jomo Kenyatta International Airport, Nairobi' terms. Before the flowers left Jomo Kenyatta International Airport, some of the flowers were sold to third-party exporters at a significantly higher price; they then exported the flowers to Europe and other markets served by Flower Express. The price charged by Flower Express to third-party exporters was used by the KRA as an internal comparable for CUP, and the price between Karuturi and Flower Express was adjusted appropriately. Although the details of the case itself remain outside the public domain, press reports suggest that subsequent negotiations resulted in a reduction of the tax bill from Ksh2 billion to Ksh500 million (approx. US\$200 million to US\$50 million). This case contributed to public controversy around tax evasion by MNEs in Kenya. Perhaps as a result, the Kenyan company was placed into receivership in April-May 2016, although it was reported that its main assets (land and some agricultural equipment) were owned by its sister companies (Muchiri 2016). Despite the limited information available, the KRA continues to stand by the audit and assessment of its TP unit.

Despite the failure to conclude the Karuturi case, it was reported that three other major audits resulted in companies accepting the adjustments, and paying the amounts specified. ${ }^{16}$ This may have been a result of the risk of possible reputational damage, as seen in the example of the Karuturi case. However, since the names of the companies and details of the cases are unknown, it remains unclear whether and how the companies in question modified their previous declarations. This payment may have contributed to the increased revenue collection of US $\$ 1$ million in 2013 , when KRA surpassed its annual target as seen in Figure 5 below. ${ }^{17}$

Table 5 compares actual taxes collected from corporation tax to KRA's total tax collection targets between 2005 and 2015. There are two problems with the figures: first, corporate tax collection targets are not publicly available; second, corporation tax figures shown include capital gains tax. The latter figure is likely to be very small, as capital gains tax was only reintroduced in 2014. The data in Table 5 is illustrated in Figure 3, which shows the share of corporate tax compared to total tax collection. 
Table 5 Tax collection $2005 / 6$ to $2014 / 15$ (millions of US\$)

\begin{tabular}{|l|l|l|l|l|}
\hline Fiscal Year & $\begin{array}{l}\text { Corporate tax } \\
\text { collected }\end{array}$ & Total tax target & $\begin{array}{l}\text { Total tax } \\
\text { collected }\end{array}$ & $\begin{array}{l}\text { Percentage } \\
\text { change from } \\
\text { previous year }\end{array}$ \\
\hline $2005 / 6$ & 54,144 & & 309,416 & \\
\hline $2006 / 7$ & 61,144 & & 371,989 & $+17 \%$ \\
\hline $2007 / 8$ & 79,125 & & 441,530 & $+16 \%$ \\
\hline $2008 / 9$ & 85,844 & & 502,096 & $+12 \%$ \\
\hline $2009 / 10$ & 103,655 & & 577,253 & $+13 \%$ \\
\hline $2010 / 11$ & 97,972 & 641,200 & 542,945 & $-6 \%$ \\
\hline $2011 / 12$ & 127,995 & 733,400 & 651,410 & $+17 \%$ \\
\hline $2012 / 13$ & 154,134 & 881,000 & 725,521 & $+10 \%$ \\
\hline $2013 / 14$ & 170,917 & 973,500 & 830,319 & $+13 \%$ \\
\hline $2014 / 15$ & 208,002 & $1,180,000$ & $1,006,862$ & $+18 \%$ \\
\hline
\end{tabular}

Source: Author, derived from ICTD database; tax targets from KRA website; no inflation adjustment

Figure 3 Tax collection, 2005/6 to 2014/15 (from Table 3)

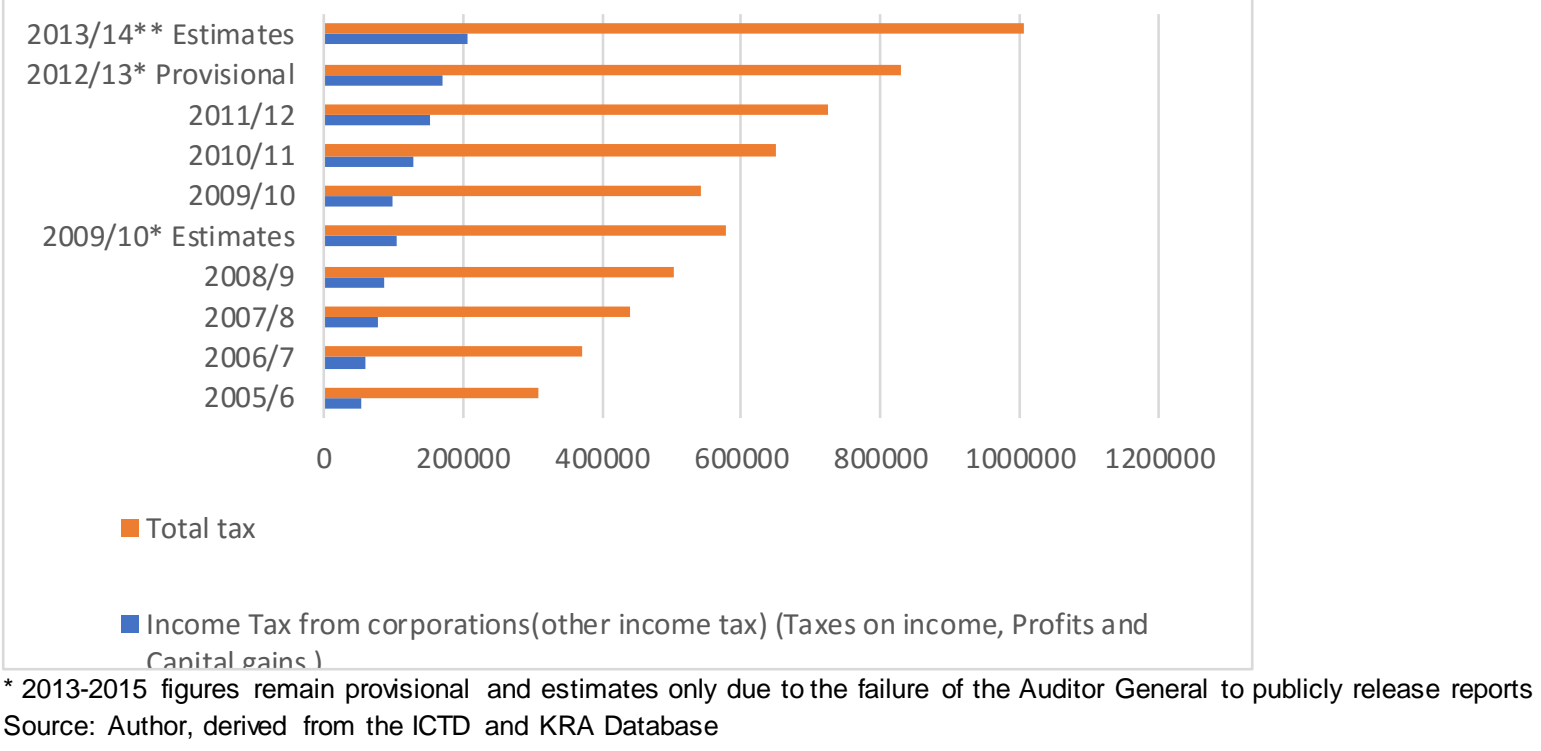

Figure 3 shows that taxes overall, as well as corporate tax, are growing. There is, therefore, a possible correlation between the capacity of KRA to understand and implement TP rules, and the increase in collection. Table 5 above shows that apart from 2013/2014 fiscal year, over the past four years KRA has revised its targets downwards repeatedly in the course of the year, and failed to reach the projected target despite increasing collection (BD Reporter 2014).

There were two other legislative changes enacted in 2013 and 2014 to tighten the TP framework. First, in recognition of increasing cases of transfer mispricing in relation to value added tax (VAT), the Value Added Tax Act, 2013 was amended to ensure that prices applied between related parties are at arm's length. Section 13(1) (b) requires that, in determining the value of a supply in the case of related parties, the price shall be the open market value. The open market value is a similar concept to the arm's length price. Subsection 8 defines a 
related person as a person or third party who participates directly or indirectly in the management, control or capital of the business.

Second, a regulation was enacted under section 18(3) of the Income Tax Act in 2014, allowing for the issue of advance pricing agreements (APAs). ${ }^{18}$ In addition, section 30 of the Tax Procedure Act (2015) allows for the issue of advance assessments, which could be an alternative route to follow. However, these procedures have not yet been utilised, arguably because the KRA is not ready to issue either document yet, as it does not have sector-wide information. ${ }^{19}$ In addition, the KRA does not have the capacity to verify whether companies comply with an APA. APAs are perceived as part of co-operative compliance, and the KRA Investigation Department has been receiving training from the Swedish Tax Agency and Italian Revenue on its implementation of co-operative compliance. ${ }^{20}$ Finally, sections $62-69$ of the Tax Procedure Act (2015) grant the Commissioner General the power to issue public and private rulings through a diverse palate of potential issues, including and not limited to individual transactions. ${ }^{21}$

In conclusion, one can see that Kenya has grappled with the problems of assessing and auditing TP transactions for over a decade. Some progress has been made, although the process has been neither smooth nor easy. Section 3 looks in detail at the challenges and successes of KRA in understanding and implementing TP rules in its audits and assessments, and proposes solutions.

\section{Current TP challenges and successes}

Kenya has come a long way since the Unilever case, when staff were mostly untrained in TP and there were no TP regulations or comparables. The KRA now has teams of trained staff who collect taxes based on strengthened TP regulations, using a comparables database. Kenya's historical background, outlined in Section 2, allows reflection on and analysis on the effects of the process of reforms and capacity building under current OECD TP rules. The findings here are broken down into: legal framework, capacity, audit process, governance and technical obstacles.

\subsection{Legislative framework}

The Unilever case showed that the judge found the law insufficient. Since case law forms precedent, the Unilever case has adversely affected TP collection. ${ }^{22}$ All similar cases have had to be abandoned until legislation has been amended. It is important that that the judiciary and Tax Appeal Tribunal call upon independent experts to assist them in understanding technical issues.

Although many reforms are now in place, there are not enough. Identified concerns include: lack of clarity on where in the KRA to file TP policy that is submitted with the self-assessment form; no prescribed forms to fill in; no prescribed database to assist in choice of method and its application; and no guidance on the method selected.

\footnotetext{
$18 \quad$ An APA is an ahead-of-time agreement between a taxpayer and a tax authority on an appropriate transfer pricing methodology for a set of transactions at issue over a fixed period of time (called covered transactions) (Legal IQ 2017). Interview 9.

Interview 11 and 12.

A tax ruling in Kenya is a decision made by the Commissioner General and is a decision or opinion of the revenue authority in respect of actual situations. It comes in advance before the fact as part of an assessment procedure or in response to taxpayer questions.

$22 \quad$ Interview 9.
} 
In addition, as issues surrounding TP have been in flux since the development of the OECD BEPS project, the legal and policy unit needs to be constantly prepared to provide amendments to law and policy for the Ministry of Finance to present to parliament as well as to issue regulations - similar to the Davis Tax Committee in South Africa. However, the government of Kenya does not seem to be considering this.

\subsection{Capacity}

The process of a TP audit is conducted only by the twelve-member TP unit (which falls under the Large Taxpayers Office (LTO)). No other department in the KRA looks into this issue. The current unit is divided into two teams of five members, with a sixth member as supervisor. As it is still a very new unit, they only have between two-three years of training, and five-six years of experience, and have only received basic TP training. Training is currently being provided by the OECD, IMF, Commonwealth Association of Tax Administrators and ATAF, and predominantly to those in the TP unit, the legal unit, dispute resolution unit and policy unit.

It is necessary not just to continue to build and maintain capacity within the KRA, but also other parts of government that touch upon it. Public awareness needs to be raised to ensure their assistance in improving tax collection. ${ }^{23}$

On the positive side, the unit has had low staff turnover over the first six years; all trained staff were staying within KRA, although a few were reassigned to other KRA departments. This recently changed with the promotion of one supervisor to deputy commissioner; the departure of the unit's head to work at the OECD-based Tax Inspectors without Borders in early 2016; and one member of the dispute resolution team (who is also a mining tax specialist) moving to the Global Policy Centre at the Business and Economics University of Vienna. Turnover may become a concern in the next few years, especially once BEPS project reforms have been implemented. ${ }^{24}$ However, staff may not want to leave while they can access training and gain practical experience, since this programme is keeping them exposed to cutting edge issues.

Despite the relative stability of the unit, some tax advisors interviewed consider that five or six of the twelve staff in the unit have a good depth of knowledge. The central problem remains the need for a deep understanding of specific industry sectors that can be widely different - for example, the petroleum industry and foreign exchange trading. As a result, despite improved capacity, the audit itself takes on average two to three years, and completion of a matter takes four to five years. ${ }^{25}$ While capacity in the KRA has improved, no members of the Tax Appeals Tribunal, judiciary or parliament have received training that would allow them to better understand this very complex issue.

\subsection{The audit process}

There are several ways that a potential transfer mispricing issue is identified at KRA - a tipoff from a multinational company or media reports, when audit staff notice something during a general audit, or through systematic audit of MNEs by staff of the TP unit.

In the first scenario - a tip-off - three tax audit cases were settled after public statements made in the press and on the internet were cross-referenced with tax data filed at the KRA. ${ }^{26}$

Interview 2

Interview 11.

Interviews 7 and 8 .

Interview 11. 
In the second scenario, a tax auditor discovering a potential issue of TP, the case is immediately forwarded to the TP unit. Since this is a general audit and includes other issues, private accountants and auditors interviewed noted that in some cases TP concerns were not picked up even at the in-depth audit stage. Instead other simpler tax errors were dealt with outside the TP unit, resulting a clean bill of health. ${ }^{27}$

Under the third scenario, a risk-based approach has been taken by the TP unit. First, companies to be audited are identified using several risk indicators from a review of returns and transfer pricing documents filed with the KRA. The risk indicators include identifying countries that have previously engaged in transfer mispricing. MNEs operating in countries known to harbour companies that have evaded taxes in the past are placed under scrutiny. ${ }^{28}$ The TP unit also looks for other indicators, including a fall in tax receipts from an industry, a drop in the amount of data reported, and differences between actual physical activity and the data in the documentation presented for reporting purposes. The procedure followed is to audit one company first, and see if there is an issue that may be more widespread - in which case the audit will extend to the whole industry. Other markers include looking at VAT returns to see who sold to whom, and to check the corresponding company. They also look at news reports to identify when a company is showing lower profits - either in comparison with other companies, or simply where they have fallen without reason. ${ }^{29} \mathrm{KRA}$ officials are aware that 'tax evasion could not take place without the assistance of the Kenyans working within these sectors, and that this enabled the system of abuse of the related parties concept'. ${ }^{30}$ In conclusion, it seems that the most effective way to identify targets seems to be through being tipped off. Finally, any TP issues identified by other audit teams are forwarded to the TP unit for consideration.

After identification of a company, a team of two auditors in the TP unit conduct a basic compliance audit. If no TP issues are identified, the company is not pursued further. However, if TP issues are identified, the same team goes on to do an in-depth audit. During the in-depth audit there are negotiations and discussions within the TP unit on the parameters used to make the assessment. This includes calling on key personnel at the MNE concerned, either to request additional documentation or to interview them for information. The TP unit records such interviews, and a transcript of the meeting is sent to the specific interviewee to sign off to confirm the content. Examples of compliance issues mentioned by TP unit members interviewed were that those who arrived at the KRA for interviews may refuse to sign the transcript, or may request that a part be removed. ${ }^{31}$ An assessment is then issued. If the issues within the assessment are agreed upon by negotiation and settled, the matter ends there. However, if the company fails to agree with the assessment and negotiations fail, the taxpayer can appeal to the Tax Appeals Tribunal. The Investigation Department is only called in for cases of potential criminality. ${ }^{32}$

Although there was no exact data available on how many cases progress to each stage, it seems that most cases are dealt with at the first stage of a basic compliance audit; only 1 per cent of cases escalate to an in-depth audit. The in-depth audit team chooses which of the 1 per cent to proceed with. On average it is able to proceed with less than 10 per cent of them, mainly due to limited resources. ${ }^{33}$ This effectively means that only 0.1 per cent of cases result in an in-depth audit. Very few cases go to the Investigation Department, and the taxpayer is generally anxious to avoid this stage.

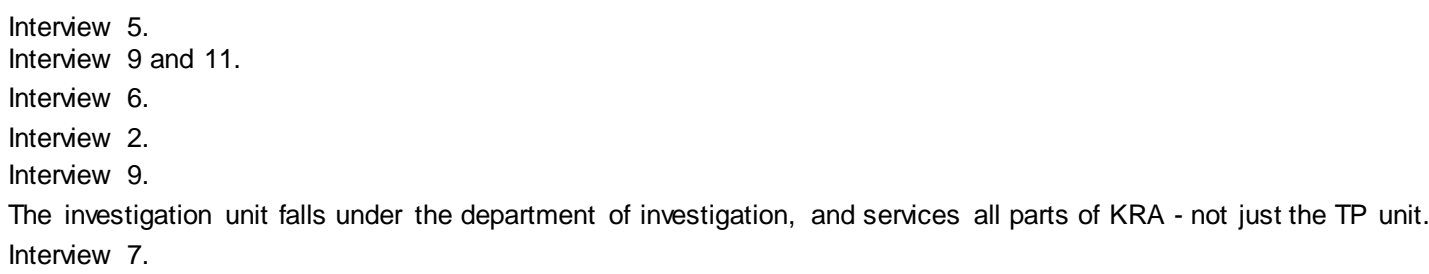




\subsection{Governance}

Despite the swiftness in joining the Global Forum and MAP process, and the reform of laws related to the Unilever case, several treaties remain unratified. Kenya has signed eight TIEAs, as shown in Table 1, but not a single one has been ratified. The process of negotiating and signing TIEAs took more than three years, and this reflects a lack of political will in Kenya to join in the sharing of information. ${ }^{34}$ Since Kenya signed the Multilateral Convention on Mutual Administrative Assistance in Tax Matters (MCMAATM) in February 2016, it could be said that the TIEAs are no longer needed - all the countries with which Kenya signed TIEAS have signed and ratified the MCMAATM, except for Monaco. However, Kenya has still to ratify the MCMAATM, and its failure to ratify the TIEAs is a bad omen.

One possible reason for this lack of political will regarding exchange of tax information is that there is little separation of the state and business in Kenya, with many politicians having involvement - including a share of ownership - in both local and multinational corporations. These connections create concern about the role of the political elite and its impact on the regulation of corporate entities, as those who approve the regulations and laws in parliament are often themselves directly affected. This concern may arise from a lack of awareness in the country's political class on how information would be used and the possibility of victimisation, as well as fear of discovery of illicitly-gotten gains held abroad. KRA officials, already having difficulty with the current regulations, feel there needs to be more clarity on how this process is expected to work under BEPS.

\subsection{Technical obstacles}

After building a legal framework, ensuring there is political will and that KRA capacity is developed, the remaining challenge is to apply the TP rules to prevent profit shifting. Under current Kenyan TP procedures there are several issues that provide technical challenges particularly, access to information across borders, methods used to make the assessments and the database accessed. This sub-section assesses the challenges facing the Kenyan TP unit in these three areas.

\subsubsection{Comparables}

The lack of adequate comparables within existing databases is a problem in the case of developed countries, and practitioners are sceptical of public and secret comparables (UN 2013: 21). The data in some industries is predominantly based on small family businesses, with the result that 90 per cent of comparables between southern and northern Europe are of no effective use..$^{35}$ As a result the extension of these comparables to the developing world is not always reliable; you may only have ten years of data, without an understanding of the whole value chain. In addition, the volatility of currencies can make analysis, and later audit, of TP transactions very difficult. ${ }^{36}$

Different databases give different results not only for commodities, but also intellectual property- and royalty-based issues. KRA currently only accesses the Orbis system (Bureau van Dijk n.d.). One respondent suggested that the database to be used should be prescribed in law or by regulation. ${ }^{37}$ KRA subscribed to the Orbis database in 2011; Orbis has information on over 100 million private companies, 65 thousand listed companies and around 90 million individuals. Many taxpayers in Kenya use Amadeus, which is a sub-set of Orbis.

Interview 9. It was also pointed out that a TIEA could be quickly approved under the exemption in article (4) of the TP regulations, since these are regulatory changes.

Interview 4.

Interview 4,6 and 7 .

Interview 9. 
Because of the inherent defects in foreign databases, the comparables derived end up not giving clear results, due to the difficulty of determining appropriate adjustment for economic circumstances. Currently Orbis has 2,662,476 companies listed from Africa. It has 12,529 companies from Kenya. However, a preliminary search conducted in 2016 produced only 100 companies from different industries with complete or largely complete data after 2004. Therefore it is debatable whether this is usable at all for comparables.

In order to even begin to build a usable database of comparables, certain markers must be in place. First, the local company registry must be updated and digitised to allow for local comparables. This is a problem in Kenya, as the company registry has still not been updated; digitisation began in the mid-1990s, and remains incomplete.

Second, many foreign-owned companies in Kenya are in effect economic monopolies, and it is not possible to compare prices with those paid by locally-owned businesses. Data shows that there are approximately 300 MNEs in Kenya in consumer goods, large-scale construction, and banking and finance. Since many of these products cannot be produced by local companies, these MNEs effectively control and set domestic prices. This makes it almost impossible to place them on the same footing as a local manufacturer of goods or services, whose products tend to be more expensive than the foreign MNE's.

Third, some argue that digitisation of the economy has led to the loss of a paper trail, making an adequate audit almost impossible. Evidence rules in the court system often require hard copies; electronic copies are often considered unacceptable.

Fourth, commercial databases are compiled from accounts filed by companies with the relevant administrative bodies, and presented in an electronic format suitable for searches and statistical analysis (OECD 2010, 2015b, 2015a). Databases do not normally include data on transactions, and can only be used for comparable profit data. Inherent challenges associated with the use of databases include:

1. Databases rely on publicly available information. Information in the database is not available from all countries; unique conditions in some countries mean that these countries cannot be compared with Kenya.

2. Even where information is publicly-available, not all countries have the same amount of publicly available information about their companies.

3. Even where the same level of detail is required, the information contained therein can be significantly different depending on the legal form of the company, and whether the company is listed or not.

4. Databases are compiled and presented for non-transfer pricing purposes, making them inherently unsuitable for transfer pricing purposes.

\subsubsection{Choice of method}

There remain certain differences between Kenyan law and regulations and the OECD Transfer Pricing Guidelines which they are expected to mirror, despite all the reforms undertaken so far. First, paragraph 7 of the Kenyan TP regulations covers the methods to be applied in determination of the arm's length price. The methods included the normal five, as well as a sixth - any other method with the prior approval of the Commissioner. A similar clause can be found in transfer pricing legislation of other countries, such as Hungary, India, Israel, Taiwan and Thailand.

Second, paragraph 8 does not have preference for any method, but instead allows the taxpayer to choose which they consider most suitable. However, in practice the 
Commissioner General has been known to refuse use of other methods ${ }^{38}$ when a more suitable one is available within the first five, and there have been no challenges to this approach as yet. ${ }^{39}$ There is a potential risk to prescribing a new method in that there may be insufficient details of the methodology to be followed in its application, and the alreadyoverwhelmed TP unit's work simply gets more complex (Chege 2012, 2013). There would need to be a definition of the method and when the sixth option could be exercised, which would require additional regulations or a practice note from the Commissioner General. However, approval under this provision could be given on an ad hoc basis by the Commissioner General, although undesireable, especially if tied in under sections 62-69 of the Tax Procedure Act (2015). Currently there is predominant use of the TNNM method, since the CUP method was found problematic - as seen in the Unilever case. ${ }^{40}$

Third, paragraph 9 reiterates section 56 of the Income Tax Act, giving the Commissioner power to call for information as set out in paragraph 9 of the rules. ${ }^{41}$ However despite some taxpayers repeatedly failing to provide information, this continues unabated since there are no special penalties for failure to submit records. Finally, it was realised that the rules were not as elaborate as anticipated. From the wording of the rules, it was evident that they were based on the OECD Transfer Pricing Guidelines of 1995, ${ }^{42}$ and perhaps some reference ought to be made to the UN model. Since the court in Unilever referred to the OECD Transfer Pricing Guidelines when there were no Kenyan regulations, presumably since there are no discussions in Kenya, arguably, discussions under the OECD Transfer Pricing Guidelines could also similarly be adopted using the precedent of this case. Currently, Tanzania has a statutory provision saying that its TP regulations should be interpreted in accordance with both the OECD Transfer Pricing Guidelines and the UN Manual; this adds to concern since Tanzania is also not a member of the OECD, and has not been involved in the drafting of these guidelines - which are designed to suit OECD countries and not developing countries.

\subsubsection{Access to information}

Access to information from other tax authorities has been upon request. In the past requests have been ignored completely by some countries, including the UK. ${ }^{43}$ Recently, while the UK shared information in one case upon request, Germany declined stating that its understanding was that the information requested did not fall within the parameters of what they were expected to share. The actual information requested remained confidential and was therefore not accessible. ${ }^{44}$ As a result, the KRA are discussing the need to renegotiate the DTA with Germany. ${ }^{45}$ However, there is no data available on the number of requests

Intervew

Earlier, the OECD Transfer Pricing Guidelines ranked traditional transactional methods (CUP, cost plus and resale price) higher than transactional profit methods (TNMM and profit split). However, the 2010 version of the OECD Transfer Pricing Guidelines relaxed this requirement by providing for selection of the most appropriate method to the circumstance of each case. However, the Guidelines retain some ambivalence, e.g. in Para 2.3, on p.59 they state that where a traditional transaction method and a transactional profit method can be applied in an equally reliable manner, the traditional transaction method is preferable to the transactional profit method. Moreover, where the CUP and another transfer pricing method can be applied in an equally reliable manner, the CUP method is to be preferred.

$40 \quad$ Interview 13

41 The paragraph lists the documents that the Commissioner could demand that have a direct relevance to the transfer pricing issue. These documents relates to; the selection of the transfer pricing method, the application of the method, the global organisation structure of the enterprise, details of the transaction under consideration, the assumptions, strategies, and policies applied in selecting the method; and such other background information as may be necessary regarding the transaction.

42 Therefore to expound on the rules it became necessary to still rely on the OECD Transfer Pricing Guidelines as soft law. Details of the application of transfer pricing methods are set out in the OECD Rules. The rules provide for four transfer pricing methods namely comparable uncontrolled price method (CUP), resale price method (RPM), cost plus method (CPM) and transactional net margin method (TNMM). Traditionally TNMM is the most popular method. This method requires the use of commercial databases to establish comparables.

Interview 8.

Interview 9.

Interview 9. 
made, or whether there have been any requests for information from KRA. Hopefully, with the signed Multilateral Competent Authority Agreement (MCAA) and CbCR commitments from multinational companies and countries, KRA will be able to draw on automatic exchange of information on multinationals doing business in Kenya.

One strategy of the TP unit has been to only look into companies resident in countries that have treaties in force with Kenya, from which information could be requested. A recent provision has named the Commissioner General as the competent authority for tax treaty purposes, especially for matters of exchange of information (Government of Kenya 2016: Appendix B). Nevertheless, KRA finds it difficult to obtain information from those countries (Chege 2012, 2013). Since work is based on targets and collections, staff focus on the easier audits - those involving countries with which relations exist.

In addition to information from countries with which there is direct interaction, extensive knowledge is needed on all the other companies that form part of an MNE structure globally. This requires more domestic laws, as well as renegotiation of bilateral and multilateral agreements. The MCAA and CbCR may bridge this gap, where meaningfully accessed. There needs to be available information on investment deduction and incentives in order to calculate the real tax, and not the legislated amount, in agreeing on share of profit. This becomes important when FDI concessions are granted through policy or state-MNE contracts, which reduce the effective tax rate. This was seen in the case of Apple Computers in Northern Ireland, where the legislated tax rate was 12.5 per cent but effective payment was approximately 3 per cent. A state could opt for more information being provided through legislation, as well as changes in international tax law rules on access of information, with a single understanding of the information required.

The companies being assessed are not all from countries with which Kenya has DTAs. There is little data on home-grown Kenyan MNEs, which tend to operate predominantly in other developing countries in the region, and other domestic companies not engaged in crossborder trade, which could ideally be used to populate a comparables database. As a result, KRA may be losing out from both MNEs resident in other jurisdictions as well as MNEs resident in Kenya. ${ }^{46}$

\subsection{Some success}

Despite the challenges set out above, there has been some success. In 2015, the OECD released a statement that advice from their staff helped net KRA more than US\$23 million in a single TP case (Katz 2015). KRA Commission General, John Njiraini, on 4 March 2016, stated that the audit of over thirty multinational companies had recovered KShs 15 billion in extra taxes, while thirty other cases are pending - it is not clear if this was all from TP audits. This suggests that the KRA is raising more by applying stronger versions of the TP rules. However, there is also evidence that tax advisers are beginning to challenge some of these rulings, relating to comparability adjustments, and the KRA may not be able to maintain these higher collections (Irungu 2015).

The speed of response to documentation requests has improved, as has the availability of MNE staff, including directors, when called in for discussions. A simple request for a meeting can result in the presence of both the directors, and also more recently their legal representatives and auditors, who instruct the directors when not to answer questions. When a matter goes to the Tax Appeal Tribunal (previously the Local Committee), foreign lawyers, including foreign experts, are being brought in by the taxpayer. To date KRA has won all Local Committee cases, while it has only lost one court case: Unilever. In several instances court matters have been resolved and withdrawn before a final determination by the judge:

46 Interview 9. 
Sara Lee and Karuturi, which is still unresolved. KRA's TP unit has been appraised by several international bodies, and given a high rating.

Some comments can be made in conclusion. First, due to the complexity of transfer pricing, it seems that the teams are still too small, need more technical training, are underfinanced, and cannot as a result hire additional TP staff. However, they have the full support of the KRA, and their assessments are supported to the level of potential litigation. ${ }^{47}$ Concentrating training on the limited numbers in the KRA TP unit has meant that frontline tax auditors have not been trained how to pick up the markers of basic TP and tax avoidance or evasion issues. Second, since experience and understanding of a range of different industries are required, it is very difficult to detect risk factors. KRA officials continue to struggle - first to gain industry knowledge, before even beginning to try to apply TP rules; then they are moved on to the next case, where they start the process all over again, but in a different industry. Finally, even after gaining industry understanding, the lack of suitable comparables is one of the main impediments to being able to check whether there is any avoidance or evasion taking place.

Between 2013 and 2016 there have been huge strides made in the international tax system, especially due to the OECD BEPS project. This has resulted in extensive recommendations for changes to the global tax system. The KRA TP teams have seemingly made some significant progress in collecting taxes under the current TP regulations, but will this be enough to apply these changing rules effectively? What changes may be needed to amend or revise domestic laws in a developing country like Kenya to implement these changes? More broadly, are the proposals resulting from the BEPS project, in which Kenya has been participating, useful for Kenya, and what additional changes at the international, continental and possibly regional as well as domestic levels might be required to ensure a sustainable improvement in Kenya's tax collection through the application of transfer pricing rules? Section 4 will look into these new challenges in the light of the outcomes of the BEPS project.

\section{Analysing BEPS solutions in the Kenyan context}

The September 2014 Guidance on Transfer Pricing Documentation and Country-by-Country Reporting proposed a new Chapter $V$ to be included in the OECD Transfer Pricing Guidelines. It provides 'guidance for tax administrations to take into account in developing rules and/or procedures on documentation to be obtained from taxpayers in connection with a transfer pricing enquiry or risk assessment'. Further details about the proposed procedures for filing and access, especially to the CbCRs, were published in the Guidance on the Implementation of Transfer Pricing Documentation and Country-by-Country Reporting of 6 February 2015. The BEPS project intended to produce 'key elements' for legislative provisions (which could be adapted to local law), and for the secondary mechanisms, by April 2015. The aim is to establish common rules for documentation requirements among all countries participating in the system, to apply to all MNEs except the aviation industry, which remains exempt from BEPS. There are two core issues analysed in this paper: the documentation that a developing country revenue authority requires and where the information will be filed, stored and accessed, and how it will be shared (OECD 2015a). The Report on Action 13 was released in September 2015, and a guidance document in June 2016.

$47 \quad$ Interviews 1,2 and 3. 
The changing international landscape poses new challenges for the KRA. Kenya has been actively engaged at the OECD in the BEPS project, as one of the fourteen non-OECD nonG20 states that joined in December 2014. It has also joined the Global Forum on Transparency, as well as signing the Multilateral Convention on Mutual Administrative Assistance (although this has not yet been ratified), arguably to ensure that the international standards required for accessibility of information are fulfilled. Kenya must consider whether and how to implement the reforms introduced through the BEPS project, especially the extensive changes to the TP Guidelines, including country-by-country reporting and TP documentation requirements. The UN will be releasing revisions. A Kenyan view on this is important, for domestic clarity and regional harmony; many African countries watch Kenya very carefully before deciding which direction they choose to take.

This section sets out the results of an additional nine interviews using the questionnaire attached in Appendix A, which were conducted between November 2015 and March 2016. Interviews discussed both the legal fiscal framework and data: the type, quality and how it will be handled. They included the KRA, MNEs, accountants, lawyers and civil society. ${ }^{48}$ Challenges were identified that are faced by all the stakeholders in countries generally, and the specific problems of developing countries that deserve consideration in the domestication of these changes in international tax. The challenges discussed ranged from governance issues, confidentiality issues (in different dimensions), to specific and technical issues surrounding transfer pricing.

\subsection{The legal framework and its interpretation}

BEPS moves forward on a presumption that the tax systems of all countries are at the same level of sophistication. In most OECD countries self-assessment tax return forms are prefilled; the system in place is already interlinked with all other systems in government, and simply requires that the taxpayer confirm or vary the information that the KRA already has in calculating taxes. In Kenya, however, the Companies' Registry ${ }^{49}$ is neither updated and digitised, nor linked to the revenue authority. As a result the data that could be used to crosscheck sources is not available domestically. Although the iTax system currently being set up envisages a future where this would be possible, there is no clear timeline for completion. An attempt was made in 2013, and again in early 2017, to locate the data of several local MNEs through the registry, and the most recent data provided was 1969 or 1983 for some locallyregistered global MNEs. BEPS moves forward on the premise that incorporation documents, profit and loss and balance sheet data are accessible and available. BEPS does not take the absence of this data into account. As a result, while countries like Kenya would most likely require a little more information than an OECD member state faced with the same company's tax audit, ${ }^{50}$ most developing countries may have little or no data available at all.

Due to the major changes in global laws, policies and recommendations involved in the BEPS project and related initiatives, the Kenyan government could usefully establish a permanent advisory board of local tax experts to make suggestions for reform, similar to the Davis Tax Committee in South Africa. Given the current flux in international tax law, the policy section of a revenue authority could not possibly cope with the numerous suggestions for amendments from a fairly large revenue authority like KRA. These would also need to be reflected upon with reference to the state's fiscal and economic policy, which should be housed within the Treasury and Ministry of Finance. This could be a good solution to keeping the revenue authority aware and ahead of global rule changes, including, for example, requesting that this committee develop domestic TP rules to support the work of the TP unit.

\footnotetext{
$48 \quad$ Appendix A.

49 This is also referred to as Companies House in other jurisdictions, and is the official government public registry of all companies resident within a state. It has the additional requirement of having public access to the annual accounts of all companies accessible at a small fee. 


\subsection{Capacity}

\subsubsection{Revenue authority capacity}

A key gap is the need for knowledge and experience of the main industry sectors under audit. This was evident even within the current framework, and under the BEPS reforms such expertise will be even more important. Revisions of the Transfer Pricing Guidelines resulting from BEPS Actions 8-10 strengthen the powers of revenue authorities to re-characterise transactions, based on a functional analysis of each MNE group. This requires an in-depth understanding of business structures in the different economic sectors concerned.

This means that in addition to the strengthening of capacity on TP rules, applying them to the different types of industries will remain a challenge as long as the main thrust of TP laws and regulations continues to require this type of functional analysis. Since Kenya has twelve people working on TP, and it takes two or three people on average two to three years to complete auditing a single case, focusing on understanding another industry in the same period is an almost insurmountable obstacle. Despite the large amount of training that KRA transfer pricing specialists have been receiving, the KRA, MNE representatives and accountants interviewed were unanimous on the lack of capacity of the TP unit. The lack of industry understanding by revenue authority officials in developing countries has led to a focus primarily on formal matters. ${ }^{51}$ As a result it seems that, while there is extensive theoretical knowledge, and some growth of practical knowledge, there is still a lack of experience and knowledge on the different business models and how they are applied in different industries.

As already mentioned, since training on TP issues has been focused on the TP unit, auditors in other departments lack the knowledge to pick up TP-related issues. ${ }^{52}$ This results in both siloing of knowledge and experience, and fostering a feeling of incompetence amongst mainstream tax auditors. A remedy to be considered is that the discovery of a TP issue outside the unit should lead to the concerned auditor being allowed to work the case with the TP unit, in order to spread capacity and build awareness across all departments. For KRA to take this to the next level they are concerned about: one is a structural problem, as KRA does not do risk assessments well as the reliance on tip-offs remains key. In addition, there are not enough good people. Non-TP officers need to be identified - including outside Nairobi - to ensure audits of MNE companies based outside Nairobi are carried out more effectively. ${ }^{53}$

\subsubsection{Tribunal and judiciary capacity}

Due to the complexity of TP cases, almost every additional assessment raised following TP audits ends up being objected. Pursuant to section 86(1) b of the Income Tax Act, a taxpayer may appeal to the Tax Appeal Tribunal against the Commissioner's determination of the objection. Most transfer pricing appeal cases end up in the Tax Appeal Tribunal (previously referred to as the Local Committee). However, since the decisions remain private, data on this remains inaccessible. Tribunal members are not trained in TP, and on several occasions have indicated that TP issues are too complex for their current level of skills in tax. This poses a risk in the sense that some decisions made at the Tribunal may not be founded upon sound reasoning, or, even if they are, the rationale may not have been clearly expressed. This was the case in the Unilever case, where the judge observed: 'Unfortunately, I do not have the benefit of the reasoning by the Local Committee, and am bound therefore to consider this appeal in terms of the arguments advanced before me'.

Interviews 4, 5, 6, 7, 9 and 10 .

Interview 6 .

Interview 7. 
A similar capacity issue is likely to play out in Kenya's judiciary, largely due to the manner in which the judiciary is structured. Tax appeals are dealt with at the Commercial Court, which also handles other matters of commercial nature. This court has no judges with a specialisation in tax law. However cases involving MNEs are treated carefully, and the Unilever case took two years to be finalised within the court system. Accessing domestic experts independently on these issues is becoming of crucial concern, especially since the judiciary also has a commercial dispute resolution arm.

\subsection{Governance}

There were two concerns highlighted in the case of governance: lack of political will and corruption. As concerns lack of political will, it was pointed out that many DTAs have been pending in negotiations for several years - some more than a decade. This is seen as a sign of lack of political will from both countries in the negotiation process to provide not only the foreign, but also the local, MNEs with the ability to avoid double taxation when possible. However it also impedes the work of the revenue authority, and its ability to access data in countries with whom there is no DTA or TIEA in place. ${ }^{54}$

The MNEs and accountants repeatedly highlighted corruption in diverse ways. They expressed their concern over situations in other countries where revenue authority officials were known to have either sold data to competitors or extorted money from MNEs in exchange for not releasing their data that they had in their possession to the public. ${ }^{55}$ As a result, concerns around refusal to provide documents upon request by revenue authorities, especially in developing countries, continue to be an issue.

\subsection{Technical obstacles within existing transfer pricing regulations}

There was a lot of input on the technical issues regarding BEPS requirements. This section is therefore split into technical concerns voiced: comparables, choice of TP formula, access to information and the supply of disaggregated data.

\subsubsection{Comparables}

Globally there is a debate whether the scarcity of comparables is merely a technical issue, or if in fact the OECD-based guidelines are premised on the mistaken assumption that transactions entered into by uncontrolled parties are economically equivalent to transactions entered into by members of commonly controlled groups. As a result, it is possible that because of the impossibility of sound technical analysis using comparables, transfer pricing issues in Kenya and elsewhere are really being resolved more through political negotiation rather than by objective application of rules and regulations (Picciotto 2016; Avi-Yonah 2000).

In Kenya, the issue of comparables remains unresolved by all the legislation, regulation and policy changes in place. The post-BEPS rules will still require comparables. There will be a Toolkit on this question, which may recommend safe harbours. KRA officers come across a lot of information relevant for benchmarking in the course of their work. This information is only available to the tax administration by dint of section 125(1) of Income Tax Act, and if used would result in what are referred to as secret comparables. ${ }^{56}$ A secret comparable generally means the use of information about a taxpayer by the revenue authority to form a

Section 125. (1): An officer and any other person employed in carrying out the provisions of this Act shall regard and deal with all documents and information relating to the income of a person and all confidential instructions in respect of the administration of the Income Tax Department which may come into his possession or to his knowledge in the course of his duties as secret. 
basis of risk assessment of another taxpayer, where the second taxpayer is not given access to that information as it may reveal confidential information about a competitor's operations. Although the income tax TP rules do not have clarity on the issue of secret comparables, the rules of procedure require that 'he who avers must prove', meaning that the taxpayer must provide the Commissioner General with the data it has used to determine the arm's length price or margin as set out in section 56 of the Tax Procedure Act (2015). This means that socalled secret comparables cannot be used in Kenya. This being the case, comparables for use in benchmarking remain one of the greatest challenges in the administration of the arm's length principle. This means that local industry comparables outside a database are of no use.

\subsubsection{Choice of TP method}

Since countries have little or no data with respect to developing economies as well as the many conflict and post-conflict states in Africa, the choice of method in a developing country becomes a greater challenge. As a result many countries fall back on simple measures like net margin on sales, because that is the only thing that is realistically obtainable from thirdparty data. One respondent suggested that this in effect turns corporate income tax into a sales tax on cross-border trade. ${ }^{57}$ However, in more complex transactions the choice is usually between the transactional net margin method and the profit split method. The TNMM is commonly used by developing country revenue authorities because it allows some profit to be taxed; the MNE perspective is to look at the method with the most certainty. It is unclear whether KRA prefers one method or tries to use all of them, and what criteria they use to select a method. ${ }^{58}$ The BEPS proposals provide no additional guidance on this issue.

\subsubsection{Access to information}

The KRA approach is that, by ensuring the recognition of Kenya internationally by being part of these international benchmarks and agreements, when the time comes to access information for TP purposes MNEs and other revenue authorities will deem KRA trustworthy to handle the data, and will share information that will enable tax collection. As a result, Kenya has made several changes to both its physical infrastructure, building a special secure room to house TP-related data receive from other countries, and its regulations, in order to build trust with both other revenue authorities as well as with the MNE taxpayer. However, several issues remain unresolved.

\section{TP analysis and documentation requirements}

Following the BEPS project, three types of documentation templates (local file, master file and $\mathrm{CbCR}$ ) delineate the type of information the revenue authority will access. On the whole $\mathrm{CbCR}$ and transfer pricing documentation are a diagnostic tool for tax authorities. ${ }^{59}$. Local file and master file data does give in-depth information that is critical for a revenue authority to understand the company structure and related parties. The local file is also useful for identifying risk areas. There is no real impact on business, but simply an additional administrative process. However it is clear that the data requested from the $\mathrm{CbCR}$, master file and local file will be very helpful for revenue authorities to understand the company better before beginning an audit. ${ }^{60}$

Under current rules in Kenya, there is no clarity for companies as to where they should submit their TP policies. There should be a specific place for all MNEs to file additional 
documents that currently go to the KRA with general filing of all taxpayer data. ${ }^{61}$ This problem is growing, since increased automation of the revenue authority is making it impossible to submit additional data voluntarily if no option is given for this on the KRA iTax website - including for the master file and local file. Revenue authorities in some countries have one office for all MNEs, ${ }^{62}$ and the KRA could consider instituting an office like this, to be the repository for TP policy documents. Concern about access to information stemming from questions that MNEs consistently and repeatedly pose on protection of competition-sensitive data would then be resolved.

In addition, there are no standards on what the TP policy document should contain. It may be useful to consider OECD templates for both the master file and local file. It is, however, unclear whether the KRA plans to do so. This information needs to be elaborated at domestic level through both legislation and regulation. One suggestion already in place in India is that the policy should go through the private auditor, who would then declare its truth and fairness together with the submission of the audited accounts. ${ }^{63}$ This could already be done through either the provisions on public rulings under sections 52-59 of the Tax Procedure Act, or under rule 9 of the TP Regulations (2006).

\section{Confidentiality}

The information categories of concern to MNEs were identified as: formula and recipes which have intellectual property dimensions, databases that contain client information, and data that is used in marketing or otherwise that may be critical for competitive advantage ${ }^{64}$ With these concerns in mind, it is presumed that once concerns on confidentiality, accessibility and use are addressed, sharing of data would be possible. However, under current rules, the MNEs' perspective was a preference towards revenue authorities getting information from their local MNE affiliate - one KRA official also said this is usually the quickest way to access data generally. ${ }^{65}$ However other KRA officials observed that MNEs were sometimes uneasy about disclosing global information to their local affiliates. ${ }^{66}$

The use of a central database that would require a password to access select data based on need was dismissed as utopian by MNE directors, who saw it as a threat to confidentiality and open to hacking. Questions of control, a lack of clarity on how it would operate and costs involved remain unanswered. ${ }^{67}$ It was also pointed out that the supplier of information would never be certain it would be used in the same way as in the country where it was collected. This has already come out from parliamentary sources querying whether data will be treated as confidential.

It was also stated that to ensure confidentiality the KRA needed a dedicated secure space to house data. An assessment of the physical location where data would be located - a sectioned-off corner of one floor of the KRA, where only two members of staff would be allowed to access and work with the data - passed the test when presented to MNE directors and auditors. In addition, any queries handled would be done without reference to possible TP-based concerns, to ensure the strictest levels of confidentiality. ${ }^{68}$ There was support for the BEPS aim that $\mathrm{CbCR}$ should be the same for all countries, to ease the process of access of information. ${ }^{69}$

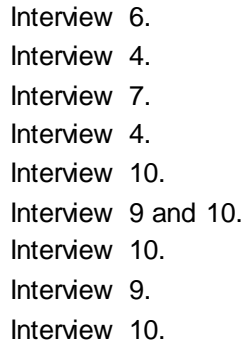


Additional concerns raised were: (a) more rules would have to be put in place before data could be sent from the tax authority head office to local offices, and (b) there will always be a large gap in perceptions between MNEs and revenue authorities. MNEs are perceived as dishonest and engaging in tax evasion, and MNEs think the revenue authority is corrupt. ${ }^{70}$ Trust, therefore, remains the biggest impediment to the exchange of information globally.

\subsection{Unresolved technical obstacles within the BEPS regulations}

Despite the aim of the BEPS process to resolve the major problems in cross-border taxation, revenue authorities like the KRA still have problems in implementing international transfer pricing rules. Among the priorities for Kenya and other developing countries, which are not addressed in the BEPS process, are:

- Major challenges in taxing the mining and transport industries.

- There is no additional data that allows for selection of one of the six TP methods. It gives some conditions, but not to the depth required. A TP report needs to contain the policy and methodology, but not the basis for an audit, in order to understand a company and the choices made. However if you need additional information, it will be counterproductive and require more administrative work for the company, with no explanation from the revenue authority. Additional questions would probably need to be phrased on: (i) transaction flows, (ii) choice of TP method, and (iii) which data was used for these choices.

- The new BEPS proposals do not make it any easier for revenue authorities to get information on sub-contracting. MNEs sometimes refuse to give information on subcontracting arrangements. In Kenya the shifting of supply of goods and services to a subcontractor may make it possible to sidestep entirely the reforms being proposed under BEPS. ${ }^{71}$

- The price data available in the databases of comparables is inadequate in various ways. It does not take into account differences in quality of products or services. In reality, the market value of, for example, roses at the point of export may vary considerably. Some are produced under special conditions and are of high quality. Others are for a mass market. The absence of comparables price data for many products is an even bigger problem.

- The issue of brokers who are related parties, but do not represent themselves as related but independent, is unresolved. In cases such as the purchase of grains and other agricultural commodities, local companies have an agreement with large MNEs and source products. They allow the broker to negotiate farmers down as low as possible, and then, instead of paying a commission to an independent broker, pay a service fee to the related party and register the profit in a low tax jurisdiction. ${ }^{72}$

- An issue that seems to have escaped the notice of OECD BEPS is that of home-grown MNEs in developing countries. All MNEs over $€ 750$ million turnover need to provide this documentation. Countries like Kenya have their own home-grown MNEs, which have already hit this threshold - for example, Kenol/Kobil and Safaricom (see Table 3). ${ }^{73}$ These companies also need to be compliant, but it remains unclear whether they are even aware of the new BEPS provisions.

Finally, another possible reason for the lack of clarity emanates from challenges in negotiations going on at state level. These may include interested states wanting to exempt particular industries from the process where they have the highest vested interest - including

This statement was repeated by many of those interviewed including KRA officials, MNE representatives and accountants.

Interview 9.

Interview 9

Interview 7. 
food commodities, aviation and shipping, and mining - as well as blocking the use of formulary apportionment.

\section{Recommendations}

The application of TP rules seems to be based on a fiction, resulting in attribution of low profits to operating affiliates. Kenya, being a developing country and predominantly a source state, is home to these affiliates. As a result even, where TP rules are being properly applied, it continues to face numerous challenges. This paper comes to two levels of recommendations.

First, there is a need for Kenyans to reflect on whether the country should be trying to implement transfer pricing rules, rely on withholding tax as an alternative, or argue the case for global alternatives like unitary taxation and formulary apportionment. ${ }^{74}$ A Kenyan equivalent of the Davis Tax Committee in South Africa may be a good forum for such a discussion.

Second, current transfer pricing rules are complex and need very skilled staff. Countries like Kenya can attempt to apply them because they get extensive capacity building. This can produce some immediate positive results, as taxpayers adjust accounts to get through the new more stringent audits. Within transfer pricing, it will first be necessary to assess the effectiveness of the arm's length rule, which seems to be causing difficulty globally, rather than simply choosing to entrench a system that seems defective.

\section{Conclusion}

As one follows the journey Kenya has taken and continues to take, certain concerns remain important at all stages.

- First, the democratic deficit in the world has led to Kenya joining the on-going processes within the OECD, where it is considered a full participant, but not a member, of the OECD. The question remains whether Kenya can be a full participant when it has joined the process late, the agenda has been set, and the solutions already decided upon by OECD member states. In effect joining now means a commitment to applying proposals decided upon by others. These do not prioritise Kenya's concerns, but rather add Kenya as an implementer of the prioritised concerns of OECD member states in a globalised world.

- Second, there are key concerns that remain unanswered, and after the BEPS project seem to have grown: capacity, comparables and access to information.

- Third, there is the continuing problem of the inability or unwillingness of governments of developing countries to engage in collective action over international tax issues. Political elites not directly involved in tax collection remain unaware of the changes required to do the job fairly.

- Fourth, while some developing countries are recipients of tax-related information under official information exchange arrangements, countries like Kenya will be both recipients and providers of information. While their processes may be partially set up to receive information, their systems for providing information are almost non-existent.

See Picciotto (2017b). 
The issues being raised in TP have been only partially resolved through capacity building and improved regulations and policy. Some additional concerns are being resolved through the BEPS project proposals. However, it is clear the process does not seem to be trying to resolve the problems created by foisting a set of complex and unwieldy rules on relatively poor developing and middle-income countries. While the BEPS project is a small step forward, it is already starting to feel like a bandage on a seeping wound. It will simply be a matter of time before the increased knowledge and experience in the developing world will force the issue and its inherent problems back to the surface, with even greater complexity.

The debate that this paper tries to unpack is whether standard international transfer pricing rules are intrinsically appropriate, but fail to work in Kenya as a result of poor capacity and other internal impediments to implementation. Those on the other side of the debate argue that the transfer pricing rules in themselves are inoperable, and therefore the entire system needs to be replaced. This paper clearly shows that, while increased capacity may in itself allow for some increased collection at the outset, in the long term the same obstacles come back to undermine effective application of the rules - in Kenya, and wherever else local institutions are unable to cope with rules designed for a very different context. 


\section{Appendices}

\section{Appendix A Country-by-country reporting survey}

1. Please state your name and position

\begin{tabular}{|l|l|}
\hline Name & Position \\
\hline & \\
\hline
\end{tabular}

2. What do you know about 'Country-by-Country Reporting'?

\begin{tabular}{|l|l|l|}
\hline A lot & Some things & Nothing \\
\hline & & \\
\hline
\end{tabular}

2.1. If you know something or a lot, how did you learn about it?

\begin{tabular}{|l|l|}
\hline Publications on the subject & \\
\hline Attendance at International ATAF Events & \\
\hline Attendance at International OECD Events & \\
\hline Attendance at Other International Events & \\
\hline $\begin{array}{l}\text { None of the above (If you mark this option, please } \\
\text { provide the manner in which you acquired knowledge on } \\
\text { the subject) }\end{array}$ & \\
\hline
\end{tabular}

3. Has your tax administration had trouble in obtaining relevant information from or about a multinational company for tax audit purposes? If so, please explain briefly the nature of the difficulty. Yes

\begin{tabular}{|l|l|}
\hline Description of the difficulty & $\begin{array}{l}\text { Mention if your TA has taken or is planning an action to solve } \\
\text { this }\end{array}$ \\
\hline & \\
\hline & \\
\hline & \\
\hline
\end{tabular}

4. Would your needs be satisfied by the information to be supplied in (i) the Country-by-Country Report, (ii) Master File, or (iii) Local File?

\begin{tabular}{|l|l|}
\hline Yes & No (Please justify) \\
\hline & \\
\hline
\end{tabular}

4.1. If you previous answer was yes, please complete the following table:

\begin{tabular}{|l|l|}
\hline Please describe your needs & $\begin{array}{l}\text { For each need, please provide the manner in which the OECD CbCR } \\
\text { proposals help satisfy your needs }\end{array}$ \\
\hline & \\
\hline & \\
\hline & \\
\hline
\end{tabular}

5. According to the OECD Guidance each country should ensure that its tax authorities have powers to obtain the Transfer Pricing Master File, and the Local File, from the local subsidiary of any multinational. They may also need the power to obtain the Country-by-Country Report, in case this is not supplied by the tax authority of the parent company. Do you consider there would be a need to amend your constitution, tax code or the regulations that address the verification and control powers of your tax administration to implement the aforementioned changes?

Yes

(If your answer is affirmative, please explain)

\begin{tabular}{|l|l}
\hline & \\
\hline
\end{tabular}

6. According to your country's laws, your Eol network and the context in which your tax administration operates, what would be the best method to have access to the Country-by-Country Report?

\begin{tabular}{|l|l|l|}
\hline Criteria & $\begin{array}{l}\text { Please mark with 'X the most } \\
\text { preferable option }\end{array}$ & $\begin{array}{l}\text { Please explain why did you chose this } \\
\text { option }\end{array}$ \\
\hline $\begin{array}{l}\text { (i) From the MNE's affiliate in your } \\
\text { country. }\end{array}$ & & \\
\hline $\begin{array}{l}\text { (ii) Through a central database (with } \\
\text { controlled access), or }\end{array}$ & & \\
\hline $\begin{array}{l}\text { (iii) From the parent company tax } \\
\text { authority. }\end{array}$ & & \\
\hline
\end{tabular}

7. If you had access, would you be able to use the information obtained by the Country-by-Country Report, (ii) Master File, or (iii) Local File in routine or general taxpayer control, audits or as proof in trials. If you would find the information useful for any other procedure, please provide it.

\begin{tabular}{|l|l|}
\hline $\begin{array}{l}\text { If you answer is YES, please provide the instances in which } \\
\text { the information would be useful. }\end{array}$ & $\begin{array}{l}\text { If your answer is NO, please provide an explanation of why } \\
\text { the information wouldn't be useful }\end{array}$ \\
\hline & \\
\hline
\end{tabular}




\section{Appendix B Authorisation of representative of competent authority}

GAZETTE NOTICE NO. 8230

The Income Tax Act

(Cap. 470)

AUTHORIZATION OF REPRESENTATIVE OF COMPETENT AUTHORITY

IT IS notified for general information that the Cabinet Secretary for the National Treasury, being the competent authority for the Agreements entered under section 41 and $41 \mathrm{~A}$ of the Act, has appointed the Commissioner-General of the Kenya Revenue Authority as the authorised representative of the competent authority for the purpose of exchange of information in tax matters.

The Commissioner-General shall act in consultation with the Cabinet Secretary in the performance of the functions attendant to this authorisation.

Dated the $16^{\text {th }}$ October, 2015.

HENRY K. ROTICH

Cabinet Secretary for the National Treasury. 


\section{Appendix C The Income Tax (Transfer Pricing) Rules, 2006}

1. These Rules may be cited as the Income Tax (Transfer Pricing) Rules, and shall come into operation on the 1st July, 2006)

2. In these Rules, unless the context otherwise requires--arm's length pricell means the price payable in a transaction between independent enterprises; -comparable transactionsll means transactions between which there are no material differences, or in which reasonably accurate adjustment can be made to eliminate material differences; -controlled transactionll means a transaction which is monitored to ensure payment of an arm's length price for goods or services; -related enterprisesll means one or more enterprises whereby-

(a) one of the enterprises participates directly or indirectly in the management, control or capital of the other; or

(b) a third person participates directly or indirectly in the management, control or capital or both.

\section{The purposes of these Rules are-}

(a) to provide guidelines to be applied by related enterprises, in determining the arm's length prices of goods and service in transactions involving them, and

(b) to provide administrative regulations, including the types of records and documentation to be submitted to the Commissioner by a person involved in transfer pricing arrangements.

4. The taxpayer may choose a method to employ in determining the arm's length price from among the methods set out in Rule 7.

\section{The guidelines referred to in rule 3 shall apply to}

(a) transactions between related enterprises within a multinational company, where one enterprise is located in, and is subject to tax in, Kenya, and the other is located outside Kenya;

(b) transactions between a permanent establishment and its head office or other related branches, in which case the permanent establishment shall be treated as a distinct and separate enterprise from its head office and related branches. Transactions subject to Rules Methods

6. The transactions subject to adjustment of prices under these Rules shall include-

(a) the sale or purchase of goods;

(b) the sale, purchase or lease of tangible assets;

(c) the transfer, purchase or use of intangible assets;

(d) the provision of services;

(e) the lending or borrowing of money; and

(f) any other transactions which may affect the profit or loss of the enterprise involved

7. The methods referred to in rule 4 are the following-

(a) the comparable uncontrolled price (CUP) method, in which the transfer price in a controlled transaction is compared with the prices in an uncontrolled transaction and accurate adjustments made to eliminate material price differences;

(b) the resale price method, in which the transfer price of the produce is compared with the resale price at which the product is sold to an independent enterprise;

Provided that in the application of this method the resale price shall be reduced by the resale price margin (the price margin indicated by the reseller); 
(c) the cost plus method, in which costs are assessed using the costs incurred by the supplier of a product in a controlled transaction, with a mark-up added to make an appropriate profit in light of the functions performed, and the assets used and risks assumed by the supplier;

(d)the profit split method, in which the profits earned in very closely interrelated controlled transactions are split among the related enterprises depending on the functions performed by each enterprise in relation to the transaction, and compared with a profit split among independent enterprises in a joint venture;

(e) the transactional net margin method, in which the net profit margin attained by a multinational enterprise in a controlled transaction is compared to the net profit margin that would have been earned in comparable transactions by an independent enterprise; and (f) such other method as may be prescribed by the Commissioner from time to time, where in his opinion and in view of the nature of the transactions, the arm's length price cannot be determined using any of the methods contained in these guidelines.

8 (1) The methods set out in Rule 7 shall be applied in determining the price payable for goods and services in transactions between related enterprises for the purposes of section 18(3) of the Act.

(2) A person shall apply the method most appropriate for his enterprise, having regard to the nature of the transaction, or class of transaction, or class of related persons or function performed by such persons in relation to the transaction.

9 (1) The Commissioner may, where necessary, request a person to whom these Rules apply for information, including books of accounts and other documents relating to transactions where the transfer pricing is applied.

(2) The documents referred to in paragraph (1) shall include documents relating to-

(a) the selection of the transfer pricing method and the reasons for the selection;

(b) the application of the method, including the calculations made and price adjustment

factors considered; 178

(c) the global organisation structure of the enterprise;

(d) the details of the transaction under consideration;

(e) the assumptions, strategies, and policies applied in selecting the method; and

(f) such other background information as may be necessary regarding the transaction.

(3) The books of accounts and other documents shall be prepared in, or be translated into, the English language, at the time the transfer price is arrived at.

10 Where a person avers the application of arm's length pricing, such person shall-

(a) develop an appropriate transfer pricing policy;

(b) determine the arm's length price as prescribed under the guidelines provided under these

Rules; and

(c) avail documentation to evidence their analysis upon request by the Commissioner.

11 The provisions of the Act relating to fraud, failure to furnish returns and underpayment of tax shall apply with respect to transfer pricing.

12 Any tax due and unpaid in a transfer pricing arrangement shall be deemed to be additional tax for purposes of Section 94 and 95 of the Act. 


\section{References}

AU/UNECA (2015) Report of the High Level Panel on Illicit Financial Flows from Africa, http://www.uneca.org/sites/default/files/PublicationFiles/iff_main_report_26feb_en.pdf

ATAF (2016) About ATAF History, <http://www.ataftax.org/en/about/Pages/History.aspx>

BD Reporter (2014) 'KRA Surpasses Tax Target, Collects Sh963.8b', 15 June 2014, $<$ http://www.businessdailyafrica.com/KRA-surpasses-tax-target--collects-Sh9638b/539552-2384536-yx67xv/index.html>

British Colonial Office (1922a) Income Tax Ordinance, Vol. 9 of 1922

(1922b) Report of the Inter-Departmental Committee on Income Tax in the Colonies Not Possessing Responsible Government, Cmd. 1788

https://archive.org/stream/reportofinterdep00grea/reportofinterdep00grea_djvu.txt

Chege, P. (2013) The Organisation Of Economic Cooperation And Development (OECD)

Transfer Pricing Guidelines: An Evaluation Of Their Effectiveness In The Kenya's Tax Regime, University of Nairobi,

http://erepository.uonbi.ac.ke/bitstream/handle/11295/60476/Chege_The\%20Organisat ion $\% 20$ Of\%20Economic\%20 Cooperation\%20And\%20Development.pdf?sequence=3\&i sAllowed=y

Corrick, L. (2016) 'Taxation Od Multinational Enterprises', in Global Tax Fairness, Oxford University Press

Dilley, M. (1966) British Policy in Kenya Colony, 2nd ed., London: Cass

Douglas, N. (2015) 'Network Analysis of the IMF Bilateral Capital Flow Data', STEAL

EAC (2016) EAC Vision 2050, <http://www.eac.int/sites/default/files/docs/eac_vision_2050web.pdf>

Economic Commission for Africa (2010) New Report on Assessing Regional Integration in Africa Features Intra- Africa Trade at the ABD Annual Meetings, Press Release No.43/2010,

Gachiri, John. 2014. 'Kenya Ranked Second in Africa as Investment Hub for Global Firms', Business Daily, Nation Newspapers, June 18,

$<$ http://www.businessdailyafrica.com/Kenya-ranked-second-in-Africa-as-investmenthub-for-global-firms/-/539552/2353266/-/118e6hiz/-/index.html>

Government of Kenya (2016) Authorization of Representative of Competent Authority, Gazette Notice No 8230 of 2016

IASB (2012) International Accounting Standard No 24, $<$ http://www.ifrs.org/Documents/IAS24.pdf>

IGD and DGDA (2011) Pioneers on the Frontier: Sub-Saharan Africa's Multinational Corporations, http://www.igdleaders.org/wp-content/uploads/IGD-Dalberg-Pioneers-onthe-Frontier.pdf 
Irungu, G. (2015) 'Tax Experts Fault KRA Standard Transfer Pricing', 27 April, http://www.businessdailyafrica.com/Tax-experts-fault-KRA-standard-transferpricing/539552-2697914-moqcjy/index.html>

Legal IQ (2017) What Is Advance Pricing Agreement?, accessed 26 April 2017, $<$ http://legaliq.com/Definition/Advance_Pricing_Agreement>

Katz, A. (2015) 'Tax Inspectors Form Cross-Border Enforcement Agency', 7 September 2015, <http://www.capecodtimes.com/article/20150709/NEWS/150709419>

Kelley, K. (2011) 'Kenya Hosts 3 of Africa's Top Multinationals', The East African, November 5

<http://www.theeastafrican.co.ke/business/Kenya+hosts+3+of+Africas+top+multination als/-/2560/1162786/-/6b170iz/-/index.html>

Kenya Colony (1941) War Taxation (Income Tax) (Amendment) Ordinance

- (1940) Income Tax Ordinance,

_ (1940a) War Taxation (Income Tax) Ordinance

KNBS (2014) 'Kenya Imports, Major Trade Partners', Kenya National Bureau of Statistics, <http://kenya.opendataforafrica.org//wjsppef/kenya-imports-major-trade-partners>

KRA (2016) Large Taxpayers Office Data, <www.revenue.go.ke/lto/ltodata.html>

M \& G Africa (2015) '10 Big Facts You Didn't Know about Kenya's Economy-for Investors Only'. MG Africa, April 9, <http://mgafrica.com/article/2015-09-03-10-things-you-didntknow-about-kenyafor-investors-only/>

Muchiri, M. (2016) 'Kenya: Karuturi Boss Laughs off Sale of His Flower Farm, Calls the Business "air"', 5 October, <http://www.standardmedia.co.ke/business/article/2000201224/karuturi-boss-laughsoff-sale-of-his-flower-farm-calls-the-business-air>

OECD (2015a) BEPS Action 13 Guidance Implementation TP Documentation CBC Reporting, <https://www.oecd.org/ctp/beps-action-13-guidance-implementation-tpdocumentation-cbc-reporting.pdf>

(2015b) Aligning Transfer Pricing Outcomes with Value Creation, Actions 8-10 - 2015 Final Reports, OECD/G20 Base Erosion and Profit Shifting Project, OECD Publishing, $<$ http://www.oecd-ilibrary.org/taxation/aligning-transfer-pricing-outcomes-with-valuecreation-actions-8-10-2015-final-reports_9789264241244-en>

- (2010) OECD Transfer Pricing Guidelines for Multinational Enterprises and Tax Administrations, <http://www.oecd.org/publications/oecd-transfer-pricing-guidelines-formultinational-enterprises-and-tax-administrations-20769717.htm>

Picciotto, S. (2017a) 'The Current Context and a Little History', in S. Picciotto (ed), Taxing Multinational Enterprises as Unitary Firms, Brighton: International Centre for Tax and Development

_ (ed) (2017b) Taxing Multinational Enterprises as Unitary Firms, Brighton: International Centre for Tax and Development 
- (2016) International Tax Disputes: Between Supranational Administration and Adjudication, Working Paper 55, Brighton: International Centre for Tax and Development

Prichard, W., Cobham, A. and Goodall, A. (2014) The ICTD Government Revenue Dataset, ICTD Working Paper 19, Brighton: International Centre for Tax and Development, 2014, <http://www.ictd.ac/datasets/the-ictd-government-revenue-dataset>

Readhead, A. (2016) Preventing Tax Base Erosion in Africa: A Regional Study of Transfer Pricing Challenges in the Mining Sector, Natural Resource Governance Institute, $<$ http://www.resourcegovernance.org/sites/default/files/documents/nrgi_transferpricing-study.pdf>

Swainson, N. (1980) The Development of Corporate Capitalism in Kenya, 1918-77, University of California Press

Tax Wise Consulting (2016) International Tax, <http://www.taxwiseconsulting.com/international-tax>

Waris, A., and Kohonen, M. (2011) 'Linking Taxation to the Realisation of the Millenium Development Goals in Africa', in Rethinking Development in an Age of Uncertainty, University of York, <http://eadi.org/gc2011/waris-109.pdf>

World Bank (2016) 'World Bank Update Says 10 Countries Move Up in Income Bracket', <http://www.worldbank.org/en/news/press-release/2015/07/01/new-world-bank-updateshows-bangladesh-kenya-myanmar-and-tajikistan-as-middle-income-while-southsudan-falls-back-to-low-income>

- (2005) World Bank Development Report 1978-2005, <http://firstsearch.oclc.org/WebZ/DCARead?standardNoType $=1 \&$ standardNo=0821357 387 :srcdbname $=$ worldcat:fromExternal=true\&sessionid $=0>$

\section{Interviews}

Interview 1 KRA Commissioner, Nairobi 2013

Interview 2 KRA Official, Nairobi 2013

Interview 3 KRA Official, TP Unit, Nairobi 2013

Interview 4 Global Tax Director MNC, Nairobi January 2016

Interview 5 Global Tax Director MNC Aviation Industry, March 2016

Interview $6 \quad$ Tax Director, Big 4 Accounting Firm, Nairobi November 2015

Interview 7 Tax Partner, Accounting Firm, Nairobi, November 2015

Interview 8 KRA Official, Nairobi 2013

Interview 9 Patrick Chege, Supervisor TP Units, LTO, KRA, Nairobi November 2015

Interview 10 James Karanja, Head of International Law, KRA, Nairobi November 2015

Interview 11 KRA Official, Nairobi November 2015

Interview 12 KRA Official LTO Office April 2016

Interview 13 Former KRA employee April 2016

\section{Statutes}

Republic of Kenya, Finance Act No. 10 of 2010

Republic of Kenya, Income Tax Act, CAP 470 of 2010 
Republic of Kenya, Tax Procedure Act, 2015

Republic of Kenya, Value Added Tax Act, 2013

Kenya Colony, Finance Ordinance 1951

\section{Cases}

Karuturi Limited v Commissioner of Domestic Taxes; Income Tax Appeal No. 7 of 2013

Sara Lee Household \& Body Care Kenya Limited v Commissioner of Income Tax (2003) AP.543

Unilever Kenya limited v The Commissioner of Income Tax (2003) AP, 753 


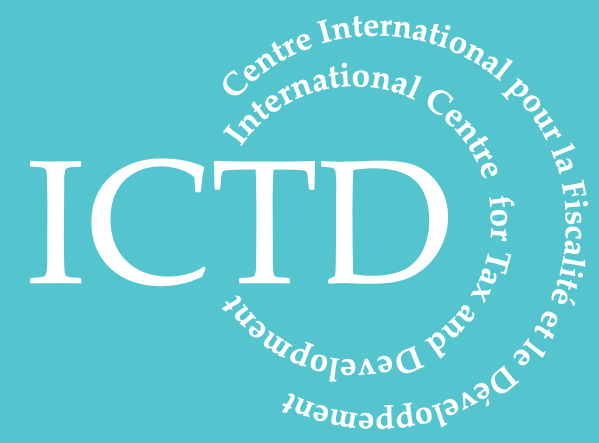

International Centre for Tax and Development at the Institute of Development Studies

Brighton BN1 9RE, UK

T: +44 (0) 1273606261

F: $+44(0) 1273621202$

E: info@ictd.ac

www.ictd.ac 